\title{
Concerned protesters: From compassion to retaliation
}

\begin{tabular}{|r|l|}
\hline Journal: & European Journal of Marketing \\
\hline Manuscript ID & EJM-03-2016-0145.R3 \\
\hline Manuscript Type: & Original Article \\
\hline Keywords: & $\begin{array}{l}\text { compassion, sympathy, anger, irresponsible corporate behavior, corporate } \\
\text { social irresponsibility }\end{array}$ \\
\hline \multicolumn{2}{|l}{} \\
\hline
\end{tabular}




\section{Dr Walter Wymer}

Associate Editor

European Journal of Marketing

\section{Professor Nick Lee}

Editor in Chief

European Journal of Marketing

Re: EJM-03-2016-0145.R2 - Concerned protesters: From compassion to retaliation

Thank you for email offering conditional acceptance of our manuscript. We have used comments from Reviewer 1 to implement further changes to the document.

Detailed answers to each reviewer comment is provided below with a description of how we have tried to address the recommendation offered.

\section{Yours Sincerely}

The Authors 


\section{Answers to Reviewer 1 comments}

The authors have made a number of substantial changes to the paper. There are still a few issues that might need to be addressed.

The opening of the paper suggests that compassion is the main driver, but might the egregiousness of the issue be more a driver, that is the worse the 'injustice' is perceived rather than necessarily compassion for the person or persons harmed? Thus people react to punish offending firm rather than because of compassion for those who are harmed? Thus, better arguing that compassion is critical may be warranted. I am not sure whether one can easily assess which occurs (or occurs first) in a given situation? This is supported on page 9 of the manuscript when the authors state: "Feelings as a reaction to this type of stimuli (i.e., reports or articles about CSI) are highly correlated making it difficult to disentangle the effect of each emotion."

Thank you for this comment. The focus of the manuscript is on explaining the role of compassion in decisions to protest against unethical behavior. We do not wish to argue that compassion is the "main driver" because the relative importance of different variables might vary depending on the specific context.

To avoid any misinterpretation, we have added the following statement at page 4: "Our argument is not that compassion is more or less important than other emotional reactions. The focus is on outlining the specific function of this emotion in the context of justice evaluations."

"Compassion and sympathy are very closely related and considered as synonyms in the context of this research." Does any additional distinction need to be made, especially as earlier in the paragraph the authors state "There is often confusion between the terms empathy, sympathy and compassion."

Thank you for raising this point. We believe that no further distinction is need but we revised the sentence to avoid any ambiguity. The sentence now reads as follows: "Compassion and sympathy are considered synonyms in the literature (Goetz et al., 2010).”

I think in the discussion of $\mathrm{H} 3$ the authors should mention attribution more explicitly in regards to CSI as they do say it is an issue, without referring to it directly.

To address this comment we included a few more sentences presenting examples of attributions from relevant research that affect sympathy. The new passage reads as follows: 
"Observers search for explanations to a negative event and sometimes this can lead to the stigmatization of the sufferers. For example, the negative consequences can be perceived as being caused by victims engaging in risky behavior, having low abilities or exerting inadequate effort (Weiner, 1983). When these attributions are activated victims will be stigmatized and observers will be less likely to experience compassion."

Should H6 be H6a and H6b to make the testing easier?

As suggested we differentiate between H6a and H6b.

The perceived suffering scale might be justified a bit more as it focuses on "negative emotions victims are expected to have endured" which is important, but there are other factors such as physical harm (as per the scenario in study 2 ).

The approach adopted is consistent with past research which has used ratings of negative emotions to assess others' perceived suffering. We clarify this issue in the methods section to stress how our measure is consistent with past research.

I am not sure that the statement "The evidence presented suggests that online petitions can represent a reputational threat to targeted organizations." Is worded correctly, as it is making people aware of the petitions is key, not the petitions existing.

Thank you for your comments. We reworded the statement as follows: "The evidence presented suggests that awareness of online petitions can represent a reputational threat to targeted organizations."

Not sure if any invariance testing is needed for the AMT sample? It is not a focal issue, but something that could be reported if the authors what to highlight generalisabity.

We agree with the reviewer that testing of structural invariance is not strictly needed for our goals. However, we have run the relevant analysis and reported the results at page 20 . We find evidence of structural invariance which supports the generalizability of the model.

In the discussion of study 2 did the authors consider looking at their control variables, Blame and fairness might also assess the suggestion that "vividness influences observers' reaction because it provides a sense of the impact: which might relate to fairness? 
Thank you for this suggestion. The reviewer seems to suggest that unfairness could perhaps replace compassion as a mediator of anger. Analyses from Study 1 however seems to contradict this argument.

More importantly we feel that both blame and unfairness are somewhat unrelated conceptually to the argument developed in Study 2. The focus is on examining the perceived consequences (i.e., impact) of events that vary in terms of vividness of the description. This does not seem to affect unfairness (i.e., to what extent corporate behaviour contradicts a moral principle) or blame (i.e., to what extent the company is perceived as responsible for the negative event). Consequently, we feel that neither unfairness nor blame relate to the findings described in Study 2.

I think the managerial implications might also consider whether adding information on corporate responses could influence relationships? That is whether forms that react quickly or slowly would then mitigate individuals protesting behaviours?

Thank you for this suggestion. We added the consideration to our list of potential implications for practice. The additional passage reads as follows: "Finally, the immediacy of the response can also have a positive impact on observers' reactions. Quick responses from companies might be most effective in reducing reactions of concern and consequently the protests these might generate." 


\section{Concerned protesters: From compassion to retaliation}

Purpose - The study outlines the unique role of compassion in reactions to cases of irresponsible corporate behavior that present information about victims of these events. Four antecedents of compassion for the victims of irresponsibility are presented and a model that explains the consequences of this emotion is tested empirically.

Design/methodology/approach - Two studies test the research hypotheses using a mix of experimental and survey research. The effects are tested both in laboratory conditions, where consumers assess a fictitious case of corporate irresponsibility, and through a test of reactions to real online campaigns.

Findings - Compassion is one of the drivers of consumers' anger at the culprit, playing an indirect role in decisions to retaliate against perpetrators. Four key drivers of compassion are identified in the research: the perceived suffering of the victims, the perceived similarity of the victims to the observer, victims' derogation and the vividness of the description of the victims.

Practical implications - The study offers insights both for campaigners wishing to instigate boycotts and organizations managing complex stakeholder relationships following a crisis. Insights on the role of compassion and its antecedents lead to more effective communications able to heighten or dampen this emotion.

Originality/value - Existing research offers contrasting views on the potential role of compassion in reactions to injustices. This study presents a novel account that clarifies previous findings and extends our knowledge of causes and consequences of compassion.

Article classification: Research paper 
Keywords: compassion; sympathy; anger; irresponsible corporate behavior; corporate social irresponsibility 


\section{Introduction}

Rosa Moreno was a worker in a factory that manufactures TVs for international brands. When she was injured in an industrial accident and lost both her hands, the company denied her compensation (e.g., Moreno, 2015). Rosa's case renewed campaigners' attention on poor working conditions within the supply chains of multinational corporations. Campaigners retell Rosa's story to generate support for petitions aimed at securing better labor conditions in developing countries (e.g., http://action.sumofus.org/a/lg-labor-protections/).

The assumption is that compassion elicited by the story will drive people to protest against companies who offer substandard conditions to their employees. Compassion is an emotion caused by the contemplation of others' suffering that is associated with helping/prosocial behavior and closely linked to one's ability to empathize with others (Gruen and Mendelsohn, 1986). Existing research, despite showing that compassion is a key driver of prosocial behavior (Loewenstein and Small, 2007), is unclear on the role that this emotion plays in reaction to injustice. While compassion should lead to the desire to help the victims of irresponsible behavior, this emotion does not appear to be a strong or reliable predictor of decisions to protest and punish the perpetrators (Fernando et al., 2014).

Literature on how moral emotions influence reactions to corporate social irresponsibility (CSI), focuses on the negative emotions of anger and contempt as determinants of decisions to retaliate (Romani et al., 2013; Xie et al., 2015). Research on the psychology of reactions to injustices offers a mixed picture. Some suggest that compassion predicts support for changes in policies but not the specific choice to punish the culprit (Pagano and Huo, 2007; Antonetti and Maklan, 2016a). Recent evidence indicates that when compassion and anger are experienced together, individuals will be more likely to act directly against perceived injustices (Antonetti and Maklan, 2016b; Fernando et al., 2014). This account, however, fails 
to clarify why compassion would motivate retaliation only when it is experienced jointly with anger.

This paper contributes to our understanding of how compassion influences reactions to cases of CSI that present information about how, and to what extent, victims of these events are being affected. We suggest that compassion serves a specific function in these circumstances: mediating the influence of information about the victims on anger. While the latter emotion generates a desire to protest, compassion facilitates punishment through reinforcing anger and ensuring that information about those harmed fuels angry responses. Our theory identifies: 1) four antecedents of compassion in reactions to CSI, 2) compassion as a cause of anger and 3) compassion as a mediator of perception of the victims on consumers' retaliations against a company.

The paper starts from a review of the relevant literature. Evidence from two empirical investigations is presented to test the hypotheses developed. Finally, we discuss the contribution of the paper to existing research.

\section{Theoretical background}

Our argument is that compassion translates feelings of care and concern for the victims into anger and retaliation. The conceptual model we develop is presented in Figure 1.

We identify four antecedents of feelings of compassion. Perceived victims' suffering is an assessment of the level of harm experienced by the victims of CSI. Perceived similarity is based on a judgment of closeness between the victims and the observer. Victims' derogation involves an evaluation of the likeability of the victims while vividness of the description relates to the level of detail used in presenting information about the people affected by CSI. Our argument is that these four dimensions influence the level of compassion and that this 
emotion, in turn, influences anger. The desire for revenge (i.e., the motivation to punish the company responsible for the case presented) is driven by feelings of anger (rather than directly by compassion). Our argument is not that compassion is more or less important than other emotional reactions. The focus is on outlining the specific function of this emotion in the context of justice evaluations.

To evaluate the validity of our theory we examine a range of potential protest behaviors. Study 1 , in the context of real online campaigns, focuses on intentions to sign a petition, the signing of the petition online and negative word of mouth. Both behaviors represent common forms of protest available to consumers. In Study 2, we assess intentions to protest against the firm as a different potential outcome variable. Our objective is to test our theory using different outcomes to examine the hypotheses under different circumstances.

We begin by reviewing research on compassion and identifying the antecedents of this emotion in reactions to CSI. Subsequently we outline the relationship between compassion and anger before discussing relevant consumer responses.

\section{INSERT FIGURE 1 HERE}

\section{Defining compassion}

There is often confusion between the terms empathy, sympathy and compassion. Although the three experiences are closely associated (Wispe, 1986; Zaki, 2014), empathy refers to the ability to take the perspective of others and re-live their own emotions (Coke et al., 1978) whilst sympathy is an emotion caused by the concern for others' suffering. Sympathy generates a desire to help those in need but is not necessarily associated with perspective taking (Goetz et al., 2010; Loewenstein and Small, 2007). Sympathy and empathy can be independent: a person can feel for others' plight without being able to experience events from 
their perspective (Decety, 2011). Compassion and sympathy are considered synonyms in the literature (Goetz et al., 2010).

Compassion is a prominent emotion in morality (Haidt, 2003). Goetz and colleagues (2010) argue that compassion evolved to favor cooperation. The primary function of the emotion is the promotion of caregiving (Haidt, 2003) triggered by appraisals of others' suffering (Goetz et al., 2010). Consistent with this approach, we examine four antecedents of compassion in relation to CSI.

\section{Antecedents of compassion in reactions to CSI}

When appraising cases of irresponsible corporate behavior, compassion originates from the perception that someone is being harmed. From this point of view, an appraisal of the victims' suffering is a key determinant of compassion. Previous research on compassion (Goetz et al., 2010) demonstrates that this emotion is often caused by the perception of negative personal events such as illness, pain, poverty, or loss in general. These conditions are signals that one is suffering or is in need of assistance. The idea that perceived suffering shapes compassion is consistent with an evolutionary approach. If sympathetic responses serve the function of signaling when others need our care then they need to be associated with an ability to appraise suffering to avoid the possibility that such feelings of concern might be exploited (Trivers, 1971). Variation in the ability to appreciate others' suffering explains feelings of compassion towards different social targets. Research on dehumanization, for example, shows that individuals can discount victims' suffering (Haslam and Loughnan, 2014). Disliked members of threatening out-groups can be seen as less able to experience uniquely human emotions and this also inhibits the ability to appreciate their suffering (Leidner et al., 2010). We expect, therefore, that the perceived suffering of victims of CSI influences feelings of compassion. 
H1: Perceived suffering has a positive influence on feelings of compassion towards the victims of CSI.

Specific appraisals of the victims are also relevant in shaping compassionate responses. An established stream of research sees perceived similarity between victims and observers as a key determinant of compassionate responses (Batson 2005; Zaki, 2014). This approach is consistent with the evolutionary perspective of compassion. Sympathetic reactions will enable in-group cohesion and kinship protection (Goetz et al., 2010). The experience of an overlap between the self and the other is a key appraisal that facilitates sympathetic reactions (Decety, 2011). Existing evidence suggests that feelings of sympathy are stronger towards victims perceived as close to the self (Stürmer et al., 2005). Recent evidence on the role of national identity in reactions to CSI also supports the idea that perceived similarity of the victims influences compassionate responses (Antonetti and Maklan, 2016a).

H2: Perceived victims' similarity has a positive influence on feelings of compassion towards the victims of CSI.

One key appraisal of compassion is the perception that victims do not deserve their plight (Goetz et al., 2010). The literature on intergroup relations shows that in many circumstances victims can be derogated; perhaps because they belong to a disliked out-group (Brewer and Kramer, 1985) or the observer is prejudiced against out-group members in general (Brewer, 1999). Attribution theory also supports the view that individuals experience sympathy towards victims only to the extent that they are perceived blameless (Weiner, 1985). Observers search for explanations to a negative event and sometimes this can lead to the stigmatization of the sufferers. For example, the negative consequences can be perceived as being caused by victims engaging in risky behavior, having low abilities or exerting 
inadequate effort (Weiner, 1993). When these attributions are activated victims will be stigmatized and observers will be less likely to experience compassion.

In reactions to CSI, it is also possible that individuals might appraise the victims as partly responsible for their suffering. Research shows that this is due to a pervasive desire to see the world as fair (Hafer and Begue, 2005). To the extent that they want to protect a view of the world as just (Lerner, 1980), individuals will find reasons to blame the victims and consequently reduce the level of sympathy they feel towards them (Kay et al., 2005).

H3: Victims' derogation has a negative influence on feelings of compassion towards the victims of CSI.

While the appraisals discussed above are all internal to the observer, the way information is presented in a specific case of CSI could also affect compassionate reactions. Experimental manipulations (see Grappi et al., 2013a), as well as real reports of irresponsible behavior, often provide information on those affected negatively. To the best of our knowledge, however, no existing research examines the impact of differences in the description presented for individual reactions. We suggest that vivid or more detailed information provided about the victims should increase compassion (rather than other emotions). Research on charitable appeals has found that single identifiable victims are more effective in generating the public's support than providing information about a large number of people affected by the same plight, that which scholars call statistical victims (Small, 2010). Although rationally, one would expect that a larger number of victims should generate a stronger desire to help, this is not the case, and people donate more for individual cases (Kogut and Ritov, 2005; Small and Loewenstein, 2003). The identified victim effect has been associated uniquely with increased compassionate responses (Erlandsson et al., 2015). Recently, scholars have argued that the identifiable victim effect is simply an instance of a larger phenomenon: people have more 
sympathy with, and react more favorably to, vivid accounts irrespective of whether one or more victims are being presented (Cryder et al., 2013). By vivid descriptions, scholars refer to detailed accounts that allow individuals to have a clearer perception of how their actions might improve the situation and alleviate others' suffering (Cryder et al., 2013). This is consistent with research on marketing communications referring to vividness as detailed and concrete descriptions which can include additional verbal information, illustrations through the use of imagery or specific examples (e.g., Keller \& Block, 1997; Kisielius \& Sternthal, 1984). In this study we test this effect in the context of CSI, examining the potential role of account vividness as an antecedent of compassion.

H4: The vividness of the victims' description influences feelings of compassion towards the victims of CSI.

\section{Discrete emotions with discrete functions: compassion as a source of anger}

Compassion should arise automatically following exposure to cases of irresponsible corporate behavior that contain information about the suffering of those affected directly and indirectly (Loewenstein and Small, 2007). What is the impact that these feelings of compassion will have on individual behavior? Researchers note the difficulty of isolating the role of different emotions in reactions to CSI. Feelings as a reaction to this type of stimuli (i.e., reports or articles about CSI) are highly correlated making it difficult to disentangle the effect of each emotion. Consequently, some accounts examine the mediating role of the CAD cluster (i.e., contempt, anger and disgust) of emotions in motivating retaliations against irresponsible companies (Grappi et al., 2013a, 2013b; Xie et al., 2015) even though anger, contempt and disgust have unique characteristics and specific functions (Fischer and Roseman, 2007). Advancing our understanding of how discrete emotional reactions explain consumer revenge, 
we suggest that compassion 1) has a specific role in individual reactions to CSI and 2) is systematically associated with feelings of anger.

The evidence on compassion's role in retaliation against injustice is mixed. Some suggest that compassion on its own is not sufficient to motivate retaliation (Fernando et al., 2014; Pagano and Huo, 2007). Fernando and colleagues (2014) find that when individuals experience compassion and anger jointly they are most likely to act. In a CSI context, there is similar evidence suggesting that consumers who experience both compassion and anger are the most likely to act (Antonetti and Maklan, 2016b). Some studies find that sympathy, despite not influencing retaliations directly, does influence general outcomes such as support for more equitable policies (Pagano and Huo, 2007) and a negative image of the irresponsible company (Antonetti and Maklan, 2016a). Although this evidence suggests that compassion brings a specific contribution to explaining people's desire to protest against injustice, the conceptual mechanism underpinning such explanatory role remains unclear.

We propose that compassion resulting from injustice to victims for whom we are presented information is best conceptualized as one of the drivers of anger. While the former communicates to the individual the need to care for the suffering of others, the latter generates the motivational force to exact revenge and strike against the perpetrator (Crossley, 2009; Grégoire et al., 2010) irrespective of the personal cost that might be involved (Bechwati and Morrin, 2003). A number of theoretical arguments supports this hypothesis.

The role of anger in consumers' retaliations is well documented (Grappi et al., 2013b; Grégoire et al., 2010) and rests on the sense of injustice that often triggers angry reactions (Antonetti and Maklan, 2016c). Irrespective of appraisals of moral fairness, anger is also triggered by the realization of personally relevant negative outcomes (Roseman et al., 1994). When individuals are affected by a perpetrator personally (O'Mara et al., 2011), or when 
victims are perceived as close to the self (Batson et al., 2009), feelings of anger are reinforced. Compassion transforms information about the victims of CSI into a personally relevant negative outcome that increases anger towards the company. After appraising others' suffering, compassion is an unpleasant emotion associated with other negative affective states (Condon and Feldman Barrett, 2013). The emotion intensifies the negative valence that characterizes feelings of anger (Russell and Fehr, 1994). Neurological evidence suggests that compassionate responses translate in an activation of areas usually linked with personally painful experiences (Decety, 2011). Compassion implies the ability to appreciate others' suffering and strengthens anger by making the corporate violation more salient (Decety and Sommerville, 2003).

Personality research has advanced the hypothesis that a tendency to be compassionate could be associated with a tendency to feel anger (Keller and Pfattheicher, 2013) because the emotions share a basic characteristic: an increased sensitivity to negative social information. Keller and Pfattheicher (2013) link hostility and compassion to an enhanced preventionfocused mode of self-regulation (Higgins, 1998) and demonstrate that this variable justifies the close connection between these two traits. This evidence supports our proposed rationale.

Functional accounts of compassion also stress its role as a communication tool (Vreeke and van der Mark, 2003; Zahavi, 2008); an inference on the suffering of others indicating that the violation is serious (Goldman, 1993). Consumers extract inferences from emotions that influence their subsequent thoughts and behaviors (Van Kleef et al., 2010). Feelings of compassion represent a signal that the violation is very severe. Since crisis severity is an antecedent of anger reactions (Antonetti and Maklan, 2016c); feelings of sympathy could also lead to higher anger.

H5: Compassion influences positively anger at the irresponsible corporation. 


\section{Emotions and motivational goals}

Emotions are associated with specific motivational goals (Roseman et al., 1994). Once anger, fueled by compassion, generates the motivation to seek revenge, consumers will develop plans to punish the corporation in order to cope with the negative emotional experience (Grappi et al., 2013a; Grégoire et al., 2010). Anger is the primary emotion of aggression (Berkowitz and Harmon-Jones, 2004). Although the specific impact of anger depends heavily on the context (Russel and Fehr, 1994), the anger script that will be activated by moral violations of CSI is primarily linked with a desire to obtain revenge (Bougie et al., 2004; Grégoire et al., 2010). A few studies also find a relationship between feelings of compassion and intentions to punish the perpetrator (Antonetti and Maklan, 2016b; Fernando et al., 2014). These investigations, however, did not examine whether both compassion and anger influence the desire to exact revenge. It is possible that some individuals perceive protest against the perpetrator as a way to help the victims. If this is the case, then it is reasonable to expect that compassion will drive protest behavior against a company because it is associated strongly with pro-social behavior (Loewenstein and Small, 2007). Borrowing from research on customer revenge (Grégoire et al., 2010), we assess whether compassion is linked with an increase in desire for revenge directly. It is expected that revenge is only directly associated with anger and that compassion is related with this construct indirectly; according to our theorizing, compassion has no direct relationship with retaliation.

H6a: Anger influences positively desire for revenge at the irresponsible corporation.

H6b: Anger mediates the influence of compassion on desire for revenge fully.

Desire for revenge and protest behavior 
In this study we examine the influence of desire for revenge in two different contexts. First, we examine desire for revenge in the context of consumers' decisions to engage with real and active online petitions. Second, we study the link between desire for revenge and intentions to protest against a corporation in laboratory conditions after participants have been exposed to a scenario describing a case of irresponsible behavior. While the lab experiment only allows to test intentions to protest, the realistic conditions of a campaign promoting online petitions are used to conduct a longitudinal study that assesses also self-reported behavior.

In recent years, there has been a rapid increase in consumer activism online (Earl and Kimport, 2011) and petitions on specific issues have been a very popular form of protest (Earl and Kimport, 2011). There are websites dedicated to online petitions (e.g., www.change.org) where campaigns sometimes target corporations for practices perceived as irresponsible. Despite their popularity, there is little research on the ability of online petitions to generate personal support for such campaigns (Fatkin and Lansdown, 2015; Kerr et al., 2012).

We assess whether desire for revenge created by exposure to an online petition influences intentions to sign the petition and the self-reported online participation in the campaign (measured three days after the initial exposure). Organizations promoting online activism obviously wish to generate further protest behavior beyond the petition. However, recent evidence points to the possibility that actually supporting a cause online might decrease individuals' intentions to act offline (Kristofferson et al., 2014). This finding seems to contradict evidence of activism that starts online and "spills over" to consumers' daily lives (Earl and Kimport, 2011). We examine specifically whether becoming exposed to an online campaign influences decisions to spread negative information about the company. Customer revenge literature shows that negative word of mouth is a common form of revenge against organizations perceived as behaving unfairly (Grégoire et al., 2010). 
Whether intentions are necessary to implement actual protest behavior in this context is unclear. The signing of an online petition is a volitional process that might require an intermediate stage when individuals make plans before acting (Ajzen, 1991). Research in service marketing, however, has suggested that desire for revenge influences punishment of the corporation directly; without the need to add consumer intentions in the model (e.g., Joireman et al., 2013). Consequently, in this study we also consider the possibility of a direct link between desire for revenge and retaliatory behaviors.

H7: Desire for revenge influences positively individuals' intentions to protest/sign a petition against the corporation.

H8: Desire for revenge influences positively the actual signing of the appeal and other protest behavior such as negative word of mouth.

H9: Intentions to sign a petition influence the actual signing of the appeal and other protest behavior such as negative word of mouth.

The research hypotheses are examined in two empirical studies. Study 1 focuses on how consumers' internal appraisals of perceived suffering, similarity and derogation influence reactions to a real online campaign. Study 2 tests through a lab experiment how variations in the vividness of the description administered influence individual reactions. Consequently, we test H4 in Study 2 while controlling for the effect of the other three independent variables to verify whether this dimension adds to our ability to predict intentions to retaliate against a corporation involved in CSI.

\section{Study 1}

Method 
Stimuli. Participants reviewed and answered survey questions in relation to one of four real online petitions. The online survey software randomly allocated the participant to one of the four petitions. Since the petition is hosted by an activist organization (http://sumofus.org/) participants had to click on a link and access the petition in a different window of their browser before returning to the questionnaire. We chose four different petitions to obtain feedback on a set of different campaigns. To ensure consistency, all petitions: 1) represent specific cases of CSI where a potential culprit was clearly identified, 2) presented clear victims and discussed their situation ${ }^{1}$.

Procedures and participants. Participants are recruited through Prolific Academic, a panel provider for online surveys and experiments. The company (www.prolific.ac) offers access to a population of around 25.000 participants. All participants are British nationals currently residing in the UK. A longitudinal design is adopted. Initially, participants complete a number of scales on the petitions reviewed. Two hundred and two participants completed the first survey. However, five failed to answer correctly to an attention check question and were therefore deleted from the dataset. All the remaining participants were invited, after two days, to complete a second survey. In the second survey, participants were invited to review the same petition again and indicate whether a) they had actually signed the petition reviewed at time 1 and b) they had engaged in negative word of mouth against the target organization. We collected 156 valid responses.

Measures. The study focuses on perceived suffering, similarity and derogation as predictors of sympathy. All items are based on the existing literature and measured on a 7-point scale (details are presented in Appendix A). A pre-test $(N=50)$ was conducted to explore the psychometric properties of the scales used. Victims' similarity assesses the relative closeness

\footnotetext{
${ }^{1}$ Each petition criticized the practices of one organization: Unilever, LG, Nevsun and Monsanto. A sample petition is available at: http://action.sumofus.org/a/lg-labor-protections/?sub=homepage),
} 
to the victims of CSI (Leach et al., 2007). The measure of victims' derogation is borrowed from the literature on justice perceptions (Skarlicki et al., 1998) and measures the general attractiveness of the victims. Perceived suffering is measured through the assessment of the negative emotions victims are expected to have endured. This approach is adapted from dehumanization research which has also operationalized in this way the extent to which observers are able to perceive suffering in others (Leidner et al., 2010). We use three items to measure anger (Joireman et al., 2013) and four to measure compassion (Goetz et al., 2010). The scale measuring desire for revenge is adapted from customer revenge literature (Grégoire et al., 2010) and measures the intention to "get even" with the firm. Three items were used to measure intentions to sign the petition reviewed. Blame attributions and perception of unfairness of corporate behavior are also measured using existing scales (Joireman et al., 2013) and considered as controls. Since research suggests that these two variables are important antecedents of anger in reaction to injustices, we verify that compassion influences anger after we have controlled for the effect of these two variables. Blame evaluates participants' view of the culpability of the organization (e.g., "Overall [company name] was... $1=$ not at all responsible; $7=$ completely responsible) while fairness registers participants' evaluation of the extent to which corporate action is perceived as ethically questionable (e.g., “[Company name]'s behavior was dishonest, 1= strongly disagree; 7= strongly agree).

Measurement model. The measures used show good reliability (Appendix A). There is also evidence of satisfactory discriminant validity demonstrated by the Maximum Shared Variance and Average Shared Variance being lower than the AVE for all latent variables (Hair et al., 2010), and evidence of support for the Fornell-Larcker criterion (Fornell and Larcker, 1981). The measurement model shows a good fit to the data $\left(\chi^{2}(d f=405, p<.001)\right.$ : $531.902 ; \mathrm{CFI}=.97, \mathrm{TLI}=.96, \mathrm{RMSEA}=.045, \mathrm{SRMR}=.057)$. Finally, there are no concerns 
in terms of multicollinearity as shown by the levels of variance inflation factor (VIF) $(<5)$ and tolerance $(>.22)$ for each construct (Hair et al., 2010). Descriptive statistics and correlations are available in Appendix B.

Common method bias $(C M B)$. The adoption of a longitudinal approach allows us to eliminate CMB for the estimation of the dependent variables (Podsakoff et al., 2003). However, CMB can still affect the variables measured in the first survey. The Harman single factor test shows that one factor explains $34 \%$ of the variance while seven factors explain $77 \%$ of total variation in the dataset. Furthermore, a single factor solution offers a very poor fit to the data $\left(\chi^{2}(d f=433, p<.001): 2736.422 ; \mathrm{CFI}=.39, \mathrm{TLI}=.35, \mathrm{RMSEA}=.19, \mathrm{SRMR}=.16\right)$. Participants' answers to the item 'I daydream and fantasize, with some regularity, about things that might happen to me," (7-point scale; from $1=$ strongly disagree to $7=$ strongly agree) was used as a "marker variable" (see Bagozzi, 2011). Answers to this item should be conceptually uncorrelated to the constructs in the model. A correlation analysis shows that all coefficients originally significant remain statistically significant after controlling for the item. Overall these results suggest that $\mathrm{CMB}$ is not a significant threat in the interpretation of our results.

\section{Results}

The objectives of our analytical strategy are to 1) verify whether our conceptual framework fits the data, 2) estimate the parameters to test our hypotheses, 3) probe the indirect effects that are implicit in the mediations suggested by our theory. The first two goals are achieved through a structural equation modelling approach (MacKinnon et al., 2002). Indirect effects, consistent with recent methodological guidelines (Hayes, 2013; Zhao et al., 2010), are 
calculated using regression analyses and bias-corrected and accelerated bootstraps to calculate the confidence intervals of the estimates ${ }^{2}$.

Different alternatives are examined to identify the model that best fits the data. The alternatives tested are based on three sets of assumptions (Table 1). Firstly, models A and B are consistent with the theory presented and vary only on whether they allow for an effect of victims' assessment (i.e., similarity, derogation and suffering) on the dependent variables or not (full mediation). Secondly, models C (full mediation) and D (partial mediation) test the alternative theoretical hypothesis: anger modeled as a predictor of compassion. Thirdly, models $\mathrm{E}$ (full mediation) and $\mathrm{F}$ (partial mediation) test compassion and anger as independent, parallel mediators both predicting customer revenge. Model C and D clearly show a worse fit than the alternatives. Model A and B are not different in terms of fit $\left(\Delta \chi^{2}=\right.$ $6.42, \Delta \mathrm{df}=6, p=.38$ ). However, Model A is preferable in terms of parsimony as indicated by the relevant indices (AIC, PGFI, PCFI). The same emerges when comparing Model A with Model E $\left(\Delta \chi^{2}=1.01, \Delta \mathrm{df}=3, p=.79\right)$ and Model $\mathrm{F}\left(\Delta \chi^{2}=6.42, \Delta \mathrm{df}=6, p=.38\right)$. Consequently, Model A, which is consistent with our theorizing, is chosen as the most parsimonious solution.

\section{INSERT TABLE 1 HERE}

Figure 2 presents the estimation of the model's parameters. The results support most of our hypotheses. Victims' similarity $(\beta=.33, p<.001)$, derogation $(\beta=-.19, p<.05)$ and perceived suffering $(\beta=.19, p<.05)$ are all significant antecedents of compassion. This variable, in turn, influences anger $(\beta=.65, p<.001)$. Consistent with H6a, when both anger and compassion are modelled as predicting customer revenge, the results show that only the

\footnotetext{
${ }^{2}$ Throughout the paper, as recommended in the literature, we calculate $95 \%$ confidence intervals using biascorrected and accelerated bootstrap with 10,000 resamples (Hayes, 2013). We use the average of the items for the analysis.
} 
former has a significant effect $(\beta=.42, p<.001)$. Furthermore, we find that customer revenge influences intentions to sign $(\beta=.48, p<.001)$ and that this variable, in turn, predicts the reported decision to sign the petition $(\beta=.28, p<.001)$ and negative word of mouth $(\beta=.21, p<.05)$. Revenge instead does not influence directly the signing of the petition $(\beta=.13, p=.157)$ and negative word of mouth $(\beta=.13, p=.319)$ a result that contradicts H8. Nonetheless, if we estimate the same model excluding the measure of intentions, there is evidence of a significant effect of revenge on negative word of mouth $(\beta=$ $.18, p<.05 ; \mathrm{R}^{2}=7 \%$ ) supporting the mediating role of intentions.

\section{INSERT FIGURE 2 HERE}

Of those who completed the survey at time $2,42\left(27 \%\right.$ of the sample) signed the petition ${ }^{3}$. To probe further the mediations suggested by our theorizing, we calculate indirect effects using PROCESS (Hayes, 2013; Model 6) to test our conceptual argument that compassion (rather than anger) mediates the effect of the cognitive appraisals of perceived suffering, similarity and derogation on desire for revenge and the behavioral outcomes. Table 2 shows the indirect effects based on our conceptual model and on a potential alternative model that inverts the role of compassion and anger. Results are consistent with our hypotheses and suggest that perception of victims of irresponsibility influence the dichotomous outcome measured at time 2 through the mediating role of compassion. Overall, the models predict a small but meaningful amount of variance in decisions to sign the petition (Nagelkerke's $\mathrm{R}^{2}$ is $12 \%$ for similarity, $13 \%$ for derogation and $14 \%$ for suffering).

\section{INSERT TABLE 2 HERE}

\section{Discussion}

\footnotetext{
${ }^{3}$ Two participants answered that they could not recall whether they had signed but stated in the text-box that they were certainly going to check and sign in case they had not already done so. Consequently, we classified these two participants as having signed the petition. We also run all the analysis excluding these two participants and their presence in the sample does not affect the results.
} 
The evidence supports our hypotheses and suggests that compassion is a mediator of the effect of cognitions about the victims on anger. Research on how consumers react to corporate injustices, as well as the study of the psychology of punishment, are both extended by the findings presented in this study significantly. The model identifies three important antecedents of compassion in reactions to CSI. This extends knowledge on how consumers appraise corporate injustices that in the past had focused predominantly on examining reactions to specific types of violations (Abosag and Farah, 2014; Farah and Newman, 2010; Grappi et al., 2013b). Perceptions of the victims are also important in shaping stakeholders' reactions (Lange and Washburn, 2012) and this research demonstrates how victims' similarity, derogation and perceived suffering represent different antecedents of individual reactions. Furthermore, the study supports the mediating role of compassion in explaining how information about the victims shapes anger and intentions to retaliate. Individual reactions of anger can be motivated by the concern felt for those affected by irresponsible behavior. When reports contain information about victims of CSI, compassion should be considered an antecedent of feelings of anger at the firm (Antonetti and Maklan, 2016c) and cannot be dismissed as an emotion unable to drive retaliatory behavior (Fernando et al., 2014). Such evidence clarifies the role played by compassion in reactions to injustices that was somewhat ambiguous following inconsistent findings in previous research (Antonetti and Maklan, 2016a; 2016b; Fernando et al., 2014; Pagano and Huo, 2007). We show that compassion 1) does not directly increase the desire for revenge, 2) does lead to more intense feelings of anger and, 3) through the mediation of anger, can be interpreted as further motive for retaliation.

The evidence presented suggests that awareness of online petitions can represent a reputational threat to targeted organizations. Twenty-seven percent of the participants have signed the petition after completing the first study and intentions to sign have a significant, 
albeit small, effect on negative word of mouth. Scholars have disputed the relative merits of online activism (Kristofferson et al., 2014). This study offers evidence that this form of campaigning represents a reputational threat for organizations.

To test further our conceptual arguments, we conduct a replication that allows validating the structural model on a different sample. Replications are considered helpful when testing causal relationships using a CB-SEM approach (Bollen and Pearl, 2012). We recruited 291 US residents on Amazon Mechanical Turk (AMT) in exchange for a small payment. AMT is an established source of data for online experiments and surveys (Paolacci et al., 2010). AMT offers access to a diverse population more representative than college students of the general US population (Paolacci and Chandler, 2014). Following guidelines, we recruited only individuals with at least $95 \%$ approval rate for their past work in the platform (Pe'er et al., 2014). The replication uses a cross sectional design and implements the same scales adopted at time 1. All measures perform adequately in terms of reliability. Discriminant validity is demonstrated by the Maximum Shared Variance and Average Shared Variance being lower than the AVE for all latent variables (Hair et al., 2010) and evidence of support for the Fornell-Larcker criterion (Fornell and Larcker, 1981). A CFA shows that the measurement model fits the data reasonably well $\left(\chi^{2}(d f=301, p<.001): 514.896 ;\right.$ CFI $=.97$, TLI $=.97$, RMSEA $=.049$, SRMR $=.054)^{4}$. The structural model fits the data well $\left(\chi^{2}(d f=312, p<\right.$ $.001): 604.58 ; \mathrm{CFI}=.96, \mathrm{TLI}=.95, \mathrm{RMSEA}=.057, \mathrm{SRMR}=.087)$. There is also evidence of structural invariance $(\Delta \mathrm{CFI}=.007)$ when comparing the replication model (US participants) with Study 1 (UK participants), which supports the generalizability of the model $^{5}$. All path estimates are statistically significant and consistent with results of the main

\footnotetext{
${ }^{4}$ Measurement invariance is established following methodological guidelines (Steenkamp \& Baumgartner, 1998). Details of the analysis are available upon request.

${ }^{5}$ The analysis is conducted using intentions to sign the petition as dependent variable for both samples.
} 
study. The model explains $49 \%$ of variance in intentions to sign the petition ${ }^{6}$. The analysis of the indirect effects (Table 3) is also consistent with our hypotheses.

\section{INSERT TABLE 3 HERE}

\section{Study 2}

\section{Method}

Stimuli. The objective of Study 2 is to test $\mathrm{H} 4$ and the role of vividness of the description within our conceptual model. The vividness of the description of the victims is manipulated in a between-subjects design. Participants read a mock news report that presented information about a large oil and gas company. In the "violation and vividness" condition, participants read about a chemical leak that affected a water basin. The description contained detailed information about the potential consequences of the leak for local victims. The "violation only" condition contained the same information about the leak without detailed description on the victims and their suffering. Details of the two scenarios are available in Appendix C. The approach follows existing research that manipulates vividness through a differentiation on the level of detailed information the participants receive (Cryder et al., 2013) and the scenario was developed on the basis of real reporting about a past case of irresponsible behavior (Moghe, 2014). We pretested the stimuli and the scales used to ensure clarity of the materials. Participants $(N=89)$ found the materials clear $(M=1.46$ on a scale from 1 : clear to 7: unclear), easy to understand ( $M=1.88$ on a scale from 1 : easy to understand to 7 : difficult to understand), and believable ( $M=1.88$ on a scale from 1: believable to 7 : unbelievable). There are no differences across conditions for all three measures $(p=.45, p=.47$ and $p=.16$ respectively).

\footnotetext{
${ }^{6} \mathrm{We}$ test for $\mathrm{CMB}$ effects and find that this factor does not represent a threat in the interpretation of the results.
} 
Procedures and participants. We recruited 200 participants on AMT using the same procedures and requirements discussed above. We positioned one attention check question towards the middle of the survey. In total six participants failed the attention check question. We delete these cases leading to a final sample of 196 participants ${ }^{7}$.

Measures. All the items are measured on a 7-point scale and based on previous research. We use the same items adopted in Study 1 to measure perceived suffering, victims' derogation, victims' similarity, desire for revenge and feelings of anger and compassion. Intentions to protest against the corporation are assessed through three items (Romani et al., 2013). In addition, we measured perceived vividness, which should vary across the two test conditions, using two items adapted from Cryder et al. (2013). Details are provided in Appendix A.

Measurement model. The measures perform well in terms of reliability and discriminant validity. Reliability indicators are above recommended thresholds for all variables (Appendix A). Discriminant validity is demonstrated by the Maximum Shared Variance and Average Shared Variance being lower than the AVE for all constructs (Hair et al., 2010), and the Fornell-Larcker criterion being supported for all constructs (Fornell and Larcker, 1981). A confirmatory factor analysis shows that the measurement model offers a reasonable fit to the data $\left(\chi^{2}(d f=319, p<.001): 460.121 ; \mathrm{CFI}=.96, \mathrm{TLI}=.96, \mathrm{RMSEA}=.047, \operatorname{SRMR}=.045\right)$ Multicollinearity does not appear to be a concern in the interpretation of the results as documented by the VIF $(<5)$ and tolerance $(>.22)$ which respect recommended thresholds for each construct (Hair et al., 2010).

Common method bias. This study adopts an experimental design and therefore CMB is less likely to represent a threat to our results. A Harman single factor test is used to rule out the existence of single dimension in the data. One factor explains $36 \%$ of the variance while six

\footnotetext{
${ }^{7}$ The inclusion of these cases does not alter the results.
} 
factors explain $74 \%$ of total variation. Furthermore, a single factor solution offers a very poor fit to the data $\left(\chi^{2}(d f=404, p<.001): 2701.254 ; \mathrm{CFI}=.38, \mathrm{TLI}=.34, \mathrm{RMSEA}=.19, \mathrm{SRMR}\right.$ $=.17)$. This evidence suggests that same source variance is not a significant threat to our analysis.

\section{Results}

The results are analyzed first by comparing means across conditions (Table 4). Confirming that the manipulation was effective, the vivid description was rated as containing more detail than the condition presenting only the violation $(t(192)=3.93, p<.001)$. Consistent with $\mathrm{H} 4$, the increased vividness in the description influences positively feelings of compassion $(t$ $(192)=3.29, p<.001, d=.47)$ but does not affect anger $(t(192)=1.54, p=.124)$. Furthermore, the two conditions do not differ on perceived similarity of the victims $(t(192)=$ $1.24, p=.217)$ or derogation $(t(192)=-1.16, p=.246)$. There is also no total impact of the manipulation on desire for revenge $(t(192)=.385, p=.700)$ and intentions to protest $(t(192)$ $=.979, p=.329)$. Suffering, however, is affected by increased detail in the level of information provided $(t(192)=2.20, p<.05, d=.31)$. This finding contradicts our conceptual model which suggests that vividness is independent of suffering (Figure 1). At the same time however our measure of vividness appears only weakly correlated to suffering $(r=$ .19), indicating only a limited conceptual overlap between the two constructs (as demonstrated also by evidence of discriminant validity in our measurement model assessment). This leads us to hypothesize the possibility that suffering might act as a mediator of the impact of vividness on compassion ${ }^{8}$.

\section{INSERT TABLE 4 HERE}

\footnotetext{
${ }^{8}$ We thank one anonymous reviewer for this suggestion.
} 
To examine this potential revision to our theory, we run a CB-SEM model using the same procedures discussed in Study 1. Perceived vividness is added to the model and we hypothesize both a path from this variable to perceived victims' suffering as well as a path from vividness to compassion. The model offers a good fit to the data $\left(\chi^{2}\right.$ ( $\mathrm{df}=330, p<$ $.001): 483.321 ; \mathrm{CFI}=.96 ; \mathrm{TLI}=.95 ; \mathrm{RMSEA}=.048 ; \mathrm{SRMR}=.079 ; \mathrm{PCFI}=.83 ; \mathrm{AIC}=$ 635.321) and the structural parameters are presented in Figure 3. The results suggest that vividness influences compassion through the mediation of perceived suffering. All other paths are consistent with Study 1, except for derogation that does not appear to be a significant predictor of compassion. This result seems reasonable because the scenarios offered no opportunity for derogation and consequently this variable is less influential than others in this context.

\section{INSERT FIGURE 3 HERE}

We also conduct a mediation analysis using PROCESS (Hayes, 2013; Model 6) to assess the entire causal chain that involves one independent variable (the manipulation of vividness), one dependent variable (intentions to protest), and four mediators in sequence (victims' suffering, compassion, anger and desire for revenge). In the analysis, the condition containing vivid information is coded as 1 while the condition containing only basic information on the violation is coded -1 . The results are presented in Table 5 and support the idea that the manipulation of vividness influences compassion through the mediation of perceived suffering. The analysis indicates a partial mediation since the effect from manipulated vividness to compassion remains significant $(\beta=.24, p<.05)$. All other effects are in line with our model and, even when including derogation and perceived similarity as controls in the analysis, we find evidence of indirect effect of vividness on intentions to protest which is consistent with our hypotheses (Zhao et al., 2010). 


\section{INSERT TABLE 5 HERE}

\section{Discussion}

Results show that vividness of information about victims' influences intentions to protest only if we take into account the role of compassion. However, although results are consistent with H4, the analysis suggests the need to revise our conceptual model and consider perceived suffering as a mediator of the impact of vividness on compassion. This finding seems consistent with the mechanism advanced by Cryder et al. (2013) whereby vividness influences observers' reaction because it provides a sense of the impact of the event on the victims. In our case, suffering is an assessment of how negative the impact of unethical corporate behavior has been for the communities affected and, from this point of view, it should be influenced by more vivid descriptions. Finally, results show that an alternative pathway, from anger to compassion, is not a suitable explanation because the manipulation has no impact on the former emotion. Compassion is responsible for making information about the victims relevant for the self and is one driver of anger when cases of CSI that affect specific victims are assessed.

The study provides evidence in support of our theoretical rationale that compassion contributes to feelings of anger and mediates the influence of information about the victims on anger reactions. The results also demonstrate that the role of compassion in retaliation is different from the influence this emotion exerts on helping decisions. While more vivid information about the victims increases directly charitable donations (Cryder et al., 2013), vivid information about victims of CSI affects retaliations only through the mediating effect of compassion. This suggests a smaller effect of compassion on retaliations and a stronger link of this emotion with helping decisions. 
We contribute to research on consumer reactions to CSI cases showing that vividness of information is one further driver of compassion and, through this effect, contributes to retaliation. We suggest that compassion has a unique function: transforming information about victims of CSI into increased intentions to protest against the company through the mediating role of anger. Feeling sorry about the plight of others creates anger against the culprit and, in this way, motivates retaliation.

\section{General discussion}

\section{Implications for research}

The paper contributes to past research on the role of compassion in observers' reactions to injustices that include information about victims affected by unethical behavior. Compassion is best conceptualized as a mediator of victims' perceptions on anger and its role is to link the sense of care for others' suffering with anger's focus on seeking revenge. Research at the intersection between CSR and Marketing studies how consumers react to cases of irresponsible corporate behavior. Past research has mostly discussed CAD emotions as mediators of consumers' retaliation (Grappi et al., 2013b; Xie et al., 2015). We extend debates in this area advocating that, when information about victims is included in a report about CSI, compassion acts as one of the drivers of anger.

Moreover, our model identifies four drivers of compassion and suggests that, depending on the circumstances, each have a unique contribution in causing compassionate responses. From this point of view, the research extends our understanding of an emotion whose study in marketing has so far mostly focused on helping/prosocial behavior (Small \& Simonsohn, 2008). The study clarifies the causes and consequences of compassion in another marketplace behavior and can offer insights useful for further research aimed at moving the study of compassion beyond existing domains. 
This analysis also extends research on how individuals react to information about those affected by corporate irresponsibility. Past research in this area mostly examined reactions to different violations (Abosag and Farah, 2014; Farah and Newman, 2010; Grappi et al., 2013b). This investigation instead demonstrates that the perception of the victims also has an influence on the emotional reactions that cases of CSI are likely to elicit (Lange and Washburn, 2012). It might be interesting in future research to integrate these two perspectives to investigate the possibility of interactions between types of violations and types of victims or victims' portrayals. This type of analysis could further extend our understanding of how stakeholders react to CSI.

Finally, the research extends evidence on online activism in the consumer domain. Past research is often skeptical of online campaigning as a tool able to generate also meaningful impact offline (Kristofferson et al., 2014). This study however finds that, at least in reactions to CSI, petitions have the ability to impact offline behaviors. We find clear evidence that intentions to sign a petition can damage a company's reputation and activate negative word of mouth. The evidence supports the view of online campaigning tools as effective means to promote social causes (Earl and Kimport, 2011).

\section{Implications for practice}

A number of important considerations for practitioners engaged in social campaigning as well as executives managing ethical crises emerge from this research. While some research may imply that compassion for the victims does not necessarily represent a threat (Fernando et al., 2014), our analysis clarifies such accounts and suggests that compassion should be considered potentially damaging for corporate reputation since it reinforces feelings of anger. Consequently, companies should monitor this emotion because of its potential consequences. 
Nevertheless, compassion whilst an indirect source of retaliation, is less powerful than anger.

This finding suggests that, whenever possible, campaigners should stress the moral anger elicited by irresponsible behavior directly rather than communicate compassion. On the other hand, several variables that trigger feelings of compassion are identified and campaigners can use these insights to produce communications that are able to elicit strong feelings of sympathy towards the victims in order to drive angry reactions. For example, our findings suggest that very vivid descriptions are able to increase compassion and consequently could trigger consumer reactions even in relatively minor cases. Furthermore, stressing victims' suffering and similarity while minimizing the possibility of derogation are important communication strategies to provoke strong reactions from the public.

Research on reactions to irresponsible corporate behavior suggests that the perceived unfairness of corporate action is the most important cause of anger. The findings presented here would suggest that, when beliefs about the propriety of a certain conduct are not clearly attributed, campaigners can focus on the presentation of the victims as a way to elicit compassion and advance their cause (Coombs, 2007). In other words, if the unfairness of corporate conduct might be controversial, compassion for those affected can be an alternative pathway to elicit anger in support of consumer protest. This finding is also important for companies as it suggests that, rather than (or in addition to) arguing on the ethicality of a certain action, firms need to ensure that they show care for those affected, in order to meet the expectations associated with the compassionate responses stakeholders are likely to experience.

Even though the study does not test response strategies directly, the insights presented offer useful information for marketers responsible for managing instances of perceived irresponsibility. The antecedents of compassion suggest areas of possible intervention, through corporate action and communications, which can facilitate containing the public's 
emotional concern for those affected. Companies should prioritize reducing the suffering of those affected to reduce the compassion experienced by external observers. Apologies can also prove effective in this context (Coombs, 2007) as a way to show concern and reduce feelings of anger which play a critical role in the chain of effects documented in this research. Finally, the immediacy of the response can also have a positive impact on observers' reactions. Quick responses from companies might be most effective in reducing reactions of concern and consequently the protests these might generate.

\section{Limitations and areas for further research}

Overall, although we find consistent evidence in support of our theorizing, the effects of victims' perceptions as mediated by compassion are rather weak in both contexts examined. This finding suggests the need to extend research to the exploration of moderating variables that might strengthen the role played by feelings of sympathy in decisions to retaliate. For example, existing research suggests that the level of identification with the party affected by CSI should strengthen the role played by compassion (Antonetti and Maklan, 2016a; Lange and Washburn, 2012; Small and Simonsohn, 2008). Following on work by Keller and Pfattheicher (2013) it is also possible to suggest that an individual tendency towards prevention in self-regulation might boost the role played by compassion. Individuals with a prevention focus should be more alert to negative social information and therefore might be increasinsly concerned by information about the plight of others (see also Xie et al., 2015).

Future research might also explore the relationships between compassion and other CAD emotions (i.e., contempt and disgust). Research suggests that contempt is a more destructive emotion than anger while disgust does not provoke punitive reactions (Romani et al., 2013). It is unclear however what their relationship with compassion might be. One possibility to examine in future research, that is consistent with the original CAD theory (Rozin et al., 
1999), would suggest that the link between compassion and these emotions is affected by the type of violation that is harming victims of CSI.

Furthermore, in our studies we measure the desire for revenge. One way to improve further our analysis would have been to consider an additional mediator measuring the desire to help the victims. According to our theory, compassion (and not anger) should influence this variable. Further research is needed to test explicitly this link. As we discussed above, it is possible that compassion might be conducive to consumer protest when this is presented directly as a way to help the victims. Past research shows that different emotions can predict different types of protest depending on how this action itself is presented (see Romani et al., 2013). Framing consumer protest as a way to help the victims would link compassion with pro-social behavior and care for others. Future research should explore empirically this possibility. 


\section{Appendix A: Measurement model for Study 1 and Study 2}

\begin{tabular}{|c|c|c|}
\hline Constructs & $\begin{array}{c}\text { Study } 1 \\
\text { Standardized } \\
\text { loadings }\end{array}$ & $\begin{array}{c}\text { Study } \mathbf{2} \\
\text { Standardized } \\
\text { loadings }\end{array}$ \\
\hline \multicolumn{3}{|c|}{$\begin{array}{l}\text { Perceived vividness of the description (1= strongly disagree; } 7=\text { strongly agree) } \\
\text { Study } 2: r=.76, \mathbf{C R}=\mathbf{. 9 5}, \mathbf{A V E}=. \mathbf{9 1} \\
\text { Source: Adapted from Cryder et al., } 2013\end{array}$} \\
\hline $\begin{array}{l}\text { The presentation contained a lot of details about the water contamination } \\
\text { case }\end{array}$ & - & .96 \\
\hline $\begin{array}{l}\text { The presentation contained very vivid information about the water } \\
\text { contamination case }\end{array}$ & - & .95 \\
\hline \multicolumn{3}{|l|}{$\begin{array}{l}\text { Perceived victims' similarity }(1=\text { strongly disagree; } 7=\text { strongly agree }) \\
\text { Study 1: } \boldsymbol{\alpha}=\mathbf{. 8 9}, \mathbf{C R}=\mathbf{. 9 2} ; \mathbf{A V E}=\mathbf{. 7 5} ; \text { Study } \mathbf{2 :} \boldsymbol{\alpha}=\mathbf{. 8 0}, \mathbf{C R}=\mathbf{. 8 7} ; \mathbf{A V E}=\mathbf{. 6 3} \\
\text { Source: Adapted from Doosje et al., } 1999 ; \text { Leach, Ellemers and Barreto, } 2007\end{array}$} \\
\hline The people mentioned in the petition are very close to me & .92 & .73 \\
\hline I am from the same group as the people mentioned in the petition & .66 & .69 \\
\hline The people mentioned in the petition are very similar to me & .81 & .85 \\
\hline I am just like the people mentioned in the petition & .90 & .88 \\
\hline \multicolumn{3}{|c|}{$\begin{array}{l}\text { Victims' derogation } \\
\text { Based on the information you read in the petition, the people affected by the company's behavior are... } \\
\text { Study } 1: \alpha=.88, \mathbf{C R}=.91 ; \mathbf{A V E}=\mathbf{. 7 3} ; \text { Study } 2: \boldsymbol{\alpha}=\mathbf{. 8 9}, \mathbf{C R}=\mathbf{. 9 3} ; \mathbf{A V E}=.77 \\
\text { Source: Adapted from Skarlicki et al., } 1998\end{array}$} \\
\hline 1: Hardworking; 7: Not hardworking & .65 & .86 \\
\hline 1: Reliable; 7: Unreliable & .87 & .88 \\
\hline 1: Dishonest; 7: Honest [reverse scored] & .88 & .87 \\
\hline 1: Cooperative; 7: Uncooperative & .81 & .86 \\
\hline \multicolumn{3}{|c|}{$\begin{array}{l}\text { Perceived victims' suffering } \\
\text { To what extent do you think the people affected by the company's behavior experienced the following } \\
\text { emotions? (1: not at all; } 7 \text { : very much) } \\
\text { Study } 1: \boldsymbol{\alpha}=\mathbf{. 9 3}, \mathbf{C R}=\mathbf{. 9 5} ; \mathbf{A V E}=\mathbf{. 8 2} ; \text { Study } 2: \boldsymbol{\alpha}=\mathbf{. 9 0}, \mathbf{C R}=\mathbf{. 9 3} ; \mathbf{A V E}=\mathbf{. 7 7} \\
\text { Source: Adapted from Leidner et al., } 2010\end{array}$} \\
\hline Anguish & .89 & .85 \\
\hline Pain & .88 & .87 \\
\hline Sorrow & .89 & .89 \\
\hline Suffering & .82 & .92 \\
\hline \multicolumn{3}{|c|}{$\begin{array}{l}\text { Compassion } \\
\text { To what extent do you feel each of these emotional reactions as a result of reading the petition? (1: not at } \\
\text { all; 7: extremely) } \\
\text { Study 1: } \boldsymbol{\alpha}=\mathbf{. 8 7}, \mathbf{C R}=\mathbf{. 9 1 ;} \mathbf{A V E}=\mathbf{. 6 7} ; \text { Study } 2: \boldsymbol{\alpha}=\mathbf{. 8 5}, \mathbf{C R}=\mathbf{. 8 9} ; \mathbf{A V E}=\mathbf{. 6 8} \\
\text { Source: Adapted from Goetz et al., 2010; Small, 2010 }\end{array}$} \\
\hline Concerned & .78 & .81 \\
\hline Compassion & .81 & .82 \\
\hline Moved & .85 & .83 \\
\hline Sympathetic & .79 & .83 \\
\hline \multicolumn{3}{|l|}{$\begin{array}{l}\text { Anger }(1=\text { not at all; } 7=\text { extremely }) \\
\text { Study } 1: \boldsymbol{\alpha}=\mathbf{8 9}, \mathbf{C R}=\mathbf{. 9 3} ; \mathrm{AVE}=\mathbf{. 8 3} ; \text { Study } 2: \boldsymbol{\alpha}=\mathbf{. 9 4}, \mathrm{CR}=\mathbf{. 9 6} ; \mathrm{AVE}=\mathbf{. 9 0} \\
\text { Source: Batson et al., } 2009\end{array}$} \\
\hline Angry & .79 & .96 \\
\hline Outraged & .88 & .93 \\
\hline Mad & .90 & .95 \\
\hline Desire for revenge $(1=$ strongly disagree; $7=$ strongly agree $)$ & & \\
\hline
\end{tabular}




\begin{tabular}{|c|c|c|}
\hline \multicolumn{3}{|l|}{$\begin{array}{l}\text { Study 1: } \boldsymbol{\alpha}=\mathbf{. 9 2}, \mathbf{C R}=\mathbf{. 9 4} ; \mathbf{A V E}=\mathbf{. 8 0} ; \text { Study } \mathbf{2 :} \boldsymbol{\alpha}=\mathbf{. 9 3}, \mathbf{C R}=\mathbf{. 9 3} ; \mathbf{A V E}=\mathbf{. 8 2} \\
\text { Source: } \text { Adapted from Grégoire et al., } 2010\end{array}$} \\
\hline I would like to take actions to get the firm in trouble & .89 & .92 \\
\hline I would like to punish the firm in some way & .87 & .93 \\
\hline I would like to cause inconvenience to the firm & .81 & .90 \\
\hline I would like to make the firm get what it deserves & .83 & .89 \\
\hline \multicolumn{3}{|l|}{$\begin{array}{l}\text { Intentions to sign the petition ( } 1=\text { very unlikely; } 7=\text { very likely }) \\
\text { Study } 1: \alpha=.92, C R=.95 ; A V E=.87\end{array}$} \\
\hline How likely is it that you will sign the petition online? & .96 & - \\
\hline How likely is it that you will share the petition with others? & .93 & - \\
\hline $\begin{array}{l}\text { How likely is it that you will encourage friends and family to sign the } \\
\text { petition online? }\end{array}$ & .80 & - \\
\hline \multicolumn{3}{|l|}{$\begin{array}{l}\text { Negative word of mouth ( } 1=\text { strongly disagree; } 7=\text { strongly agree }) \\
\text { Since reading about the petition... } \\
\text { Study } 1: \boldsymbol{\alpha}=\mathbf{9 5}, \mathbf{C R}=\mathbf{. 9 6} ; \mathbf{A V E}=\mathbf{. 8 7} \\
\text { Source: } \text { Adapted from Grégoire et al., } 2010\end{array}$} \\
\hline ...I spread negative word of mouth about the company & .90 & - \\
\hline ...I denigrated the company to my friends & .90 & - \\
\hline ...I told my friends not to buy from this company & .92 & - \\
\hline ...I complained about the company to other people & .93 & - \\
\hline \multicolumn{3}{|l|}{$\begin{array}{l}\text { Intentions to protest }(1=\text { strongly disagree; } 7=\text { strongly agree }) \\
\text { Study } 2: \boldsymbol{\alpha}=\mathbf{. 8 4}, \mathbf{C R}=\mathbf{. 9 0} ; \mathbf{A V E}=\mathbf{. 7 6} \\
\text { Source: Adapted from Romani et al., } 2013\end{array}$} \\
\hline I intend to participate in an e-mail campaign against the company & - & .83 \\
\hline I intend to boycott the company & - & .82 \\
\hline I intend to participate in a campaign against the company & - & .74 \\
\hline
\end{tabular}




\section{Appendix B: Correlations and descriptive statistics for Study 1}

\begin{tabular}{|c|c|c|c|c|c|c|c|c|c|c|c|c|}
\hline$V$ & & & 1. & 2. & 3. & 4. & 5. & 6. & 7. & 8. & 9. & 10. \\
\hline \multirow{2}{*}{$\begin{array}{l}\text { 1. Victims' } \\
\text { similarity }\end{array}$} & Mean & 2.51 & \multirow{2}{*}{1} & & & & & & & & & \\
\hline & SD & 1.29 & & & & & & & & & & \\
\hline \multirow{2}{*}{$\begin{array}{l}\text { 2. Victims' } \\
\text { derogation }\end{array}$} & Mean & 2.83 & \multirow{2}{*}{-.12} & \multirow{2}{*}{1} & & & & & & & & \\
\hline & SD & 1.30 & & & & & & & & & & \\
\hline \multirow{2}{*}{$\begin{array}{l}\text { 3. Victims' } \\
\text { suffering }\end{array}$} & Mean & 6.21 & \multirow{2}{*}{.01} & \multirow{2}{*}{$-.30^{* *}$} & \multirow{2}{*}{1} & & & & & & & \\
\hline & SD & .97 & & & & & & & & & & \\
\hline \multirow{2}{*}{ 4. Compassion } & Mean & 5.22 & \multirow{2}{*}{$.35^{* *}$} & \multirow{2}{*}{$-.40^{* *}$} & \multirow{2}{*}{$.35^{* *}$} & \multirow{2}{*}{1} & & & & & & \\
\hline & SD & 1.04 & & & & & & & & & & \\
\hline \multirow{2}{*}{ 5. Anger } & Mean & 4.61 & \multirow{2}{*}{$.37^{* *}$} & \multirow{2}{*}{$-.30^{* *}$} & \multirow{2}{*}{$.24^{* *}$} & \multirow{2}{*}{$.70^{* *}$} & \multirow{2}{*}{1} & & & & & \\
\hline & SD & 1.42 & & & & & & & & & & \\
\hline \multirow{2}{*}{$\begin{array}{l}\text { 6. Desire for } \\
\text { revenge }\end{array}$} & Mean & 4.64 & \multirow{2}{*}{$.20^{*}$} & \multirow{2}{*}{$-.29^{* *}$} & \multirow{2}{*}{$.29^{* *}$} & \multirow{2}{*}{$.40^{* *}$} & \multirow{2}{*}{$.55^{* *}$} & \multirow{2}{*}{1} & & & & \\
\hline & SD & 1.39 & & & & & & & & & & \\
\hline \multirow{2}{*}{$\begin{array}{l}\text { 7. Intentions to } \\
\text { sign the petition }\end{array}$} & Mean & 3.80 & \multirow{2}{*}{$.31^{* *}$} & \multirow{2}{*}{$-.25^{* *}$} & \multirow{2}{*}{$.16^{*}$} & \multirow{2}{*}{$.58^{* *}$} & $63^{* * *}$ & $52^{* *}$ & 1 & & & \\
\hline & SD & 1.64 & & & & & & & 1 & & & \\
\hline 8. Negative & Mean & 2.33 & 07 & $-16^{*}$ & -06 & 10 & 08 & $17^{*}$ & $22^{* *}$ & 1 & & \\
\hline word of mouth & SD & 1.47 & (0) & -.10 & -.00 & .10 & .08 & & & & & \\
\hline 9. Unfairness & Mean & 5.93 & .15 & $-.40^{* *}$ & $.34^{* *}$ & $.37^{* *}$ & $.51^{* *}$ & $.61^{* *}$ & $.43^{* *}$ & .04 & 1 & \\
\hline & SD & .94 & .15 & -.40 & .04 & & & & & & & \\
\hline 10 Blame & Mean & 6.72 & $19^{* *}$ & $-36^{* *}$ & $33^{* *}$ & $43^{* *}$ & $55^{* *}$ & $54^{* *}$ & $44^{* *}$ & .11 & $.73^{* *}$ & 1 \\
\hline 10. Blame & SD & 1.15 & & & & & & & .44 & .11 & .12 & 1 \\
\hline
\end{tabular}




\section{Appendix C: Scenarios used for Study 2}

[Both conditions] Randel Energy is an international energy company headquartered in Los Angeles and engaging in a range of different activities in the energy industry. $80 \%$ of the firm revenues come from its core business: oil and gas exploration, production, refining and distribution. Randel's downstream operations manufacture and sell products such as fuels, lubricants, additives and petrochemicals. The company's most significant areas of operations are the west coast of North America, the U.S. Gulf Coast, Southeast Asia, South Korea, Australia and South Africa. In 2010, Randel Energy sold an average 3.1 million barrels per day of refined products like gasoline, diesel and jet fuel. It is the fifth largest oil company in the world.

In May 2014 Randel has come under criticism after a large case of water contamination. A leak in a main extraction pipe has contaminated the water basin that serves the area surrounding Chartage, East Texas, US. Local journalists claim the company acted too slowly. Poor controls meant that for three days the leak went undetected. By the time engineers were at work several citizens had already noticed pollutants in the water. Authorities initially issued a two weeks ban since the water was heavily contaminated with chemicals and acids used in gas extraction. The crisis however ended only in November when the water was declared safe again for human consumption.

[Vivid violation condition only] Around 300,000 people were affected and for several weeks they couldn't drink or bathe in their tap water. In July authorities said the water could be used for domestic purposes but was still not suitable for drinking. Life was not easy for local residents who had to learn how to live without running water. People had to spend a chunk of their paychecks simply to have access to bottled water. Locals were also concerned about potential effects on health. The Center for Disease Control claimed that it "does not anticipate any adverse health effects" for the population. But "does not anticipate" feels a long way from "safe" and many locals are worried about the potential long term consequences of the spill.

[Both conditions] Almost one year on from this crisis, an investigation around the leak has led to a number of legal cases brought against the company. Three former CEOs of Randel have been indicted. The company also faces compensation claims amounting to US\$ 156 millions. Dan Farris, 58, William Thies, 60, and John E. Hansen, 63, were indicted on charges of negligent discharge of a pollutant and negligent discharge of refuse matter. They face up to three years in prison. U.S. A statement from the Department of Justice claimed it was committed to vigorously enforcing the Clean Water Act. “...The conditions at the Randel facility were not only grievously unacceptable, but unlawful. They put an entire population needlessly at risk." 


\section{References}

Abosag, I. and F. Farah, M. (2014), "The influence of religiously motivated consumer boycotts on brand image, loyalty and product judgment", European Journal of Marketing, Vol. 48 No. (11/12), pp. 2262-2283.

Ajzen, I. (1991). The theory of planned behavior. Organizational Behavior and Human Decision Processes, 50(2), 179-211.

Antonetti, P. and Maklan, S. (2016a), "Social identification and corporate irresponsibility: A model of stakeholder punitive intentions", British Journal of Management, doi: 10.1111/1467-8551.12168.

Antonetti, P. and Maklan, S. (2016b), "Identity bias in negative word of mouth following irresponsible corporate behavior: A research model and moderating effects", Journal of Business Ethics, doi: 10.1007/s10551-016-3095-9.

Antonetti, P. and Maklan, S. (2016c), "An extended model of moral outrage at corporate social irresponsibility", Journal of Business Ethics, Vol. 135, No. 3, pp. 429-444.

Batson, C. D., Chao, M. C., and Givens, J. M. (2009), "Pursuing moral outrage: Anger at torture", Journal of Experimental Social Psychology, Vol. 45 No. 1, pp. 155-160.

Batson, C. D., Lishner, D. A., Cook, J., and Sawyer, S. (2005), "Similarity and nurturance: Two possible sources of empathy for strangers", Basic and Applied Social Psychology, Vol. 27 No. 1, pp. 15-25.

Bechwati, N. N. and Morrin, M. (2003), "Outraged consumers: Getting even at the expense of getting a good deal”, Journal of Consumer Psychology, Vol. 13 No. 4, pp. 440-453.

Berkowitz, L. and Harmon-Jones, E. (2004), “Toward an understanding of the determinants of anger”, Emotion, Vol. 4 No. 2, pp. 107-130.

Bollen, K. A. and J. Pearl (2012). 'Eight myths about causality and structural equations models', In S. Morgan (ed.), Handbook of Causal Analysis for Social Research, pp. 301328, Dordrecht, Netherlands: Springer.

Bougie, R., Pieters, R., and Zeelenberg, M. (2004), “Angry customers don't come back they get back: The experience and behavioral implications of anger and dissatisfaction in services”, Journal of the Academy of Marketing Science, Vol. 31 No. 4, pp. 377-393.

Brewer, M. B. (1999), “The psychology of prejudice: Ingroup love or outgroup hate?”, Journal of Social Issues, Vol. 55, pp. 429-444.

Brewer, M. B. and Kramer, R. M. (1985), "The psychology of intergroup attitudes and behavior”, Annual Review of Psychology, Vol. 36, pp. 219-243. 
Chandler, J., Mueller, P., and Paolacci, G. (2013), "Nonnaïveté among Amazon Mechanical Turk workers: Consequences and solutions for behavioral researchers", Behavior Research Methods, Vol. 46 No. 1, pp. 112-130.

Coke, J. S., Batson, C. D., and McDavis, K. (1978), "Empathic mediation of helping: A twostage model", Journal of Personality and Social Psychology, Vol. 36 No. 7, 752-766.

Condon, P., and Feldman Barrett, L. (2013), "Conceptualizing and experiencing compassion”, Emotion, Vol. 13 No. 5, pp. 817-21.

Coombs, W. T. (2007), "Attribution theory as a guide for post-crisis communication research” Public Relations Review, Vol. 33 No. 2, pp. 135-139.

Crossley, C. D. (2009), "Emotional and behavioral reactions to social undermining: A closer look at perceived offender motives", Organizational Behavior and Human Decision Processes, Vol. 108 No. 1, pp. 14-24.

Cryder, C. E., Loewenstein, G., and Scheines, R. (2013), "The donor is in the details", Organizational Behavior and Human Decision Processes, Vol. 120 No. 1, pp. 15-23.

Decety, J. (2011), "Dissecting the neural mechanisms mediating empathy", Emotion Review, Vol. 3 No. 1, pp. 92-108.

Decety, J., and Sommerville, J. A. (2003), "Shared representations between self and other: A social cognitive neuroscience view”, Trends in Cognitive Sciences, Vol. 7 No. 12, pp. 527 533.

Earl, J., and Kimport, K. (2011). Digitally enabled social change: Activism in the Internet age. MIT Press: Cambridge, MA.

Erlandsson, A., Björklund, F., and Bäckström, M. (2015), "Emotional reactions, perceived impact and perceived responsibility mediate the identifiable victim effect, proportion dominance effect and in-group effect respectively", Organizational Behavior and Human Decision Processes, Vol. 127, pp. 1-14.

Farah, M. F., and Newman, A. J. (2010), "Exploring consumer boycott intelligence using a socio-cognitive approach”, Journal of Business Research, Vol. 63 No. 4, pp. 347-355.

Fatkin, J. M., and Lansdown, T. C. (2015), "Prosocial media in action", Computers in Human Behavior, Vol. 48, pp. 581-586.

Fernando, J. W., Kashima, Y., and Laham, S. M. (2014), "Multiple emotions: A personcentered approach to the relationship between intergroup emotion and action orientation", Emotion, Vol. 14 No. 4, pp. 722-732.

Fischer, A. H., and Roseman, I. J. (2007), "Beat them or ban them: the characteristics and social functions of anger and contempt", Journal of Personality and Social Psychology, Vol. 93 No. 1, pp. 103-115. 
Fornell, C., and Larcker, D. F. (1981), "Evaluating structural equation models with unobservable variables and measurement error", Journal of Marketing Research, Vol. 18 No. 1, pp. 39-50.

Goetz, J. L., Keltner, D., and Simon-Thomas, E. (2010), “Compassion: an evolutionary analysis and empirical review”, Psychological Bulletin, Vol. 136 No. 3, pp. 351-374.

Goldman, A. I. (1993), “Ethics and cognitive science”, Ethics, Vol. 103, pp. 337-360.

Grappi, S., Romani, S., and Bagozzi, R. P. (2013a), "Consumer response to corporate irresponsible behavior: Moral emotions and virtues", Journal of Business Research, Vol. 66 No. 10, pp. 1814-1821.

Grappi, S., Romani, S., and Bagozzi, R. P. (2013b), "The effects of company offshoring strategies on consumer responses", Journal of the Academy of Marketing Science, Vol. 41 No. 6, pp. 683-704.

Grégoire, Y., Laufer, D., and Tripp, T. M. (2010), “A comprehensive model of customer direct and indirect revenge: Understanding the effects of perceived greed and customer power", Journal of the Academy of Marketing Science, Vol. 38 No. 6, pp. 738-758.

Gruen, R. J., and Mendelsohn, G. (1986), "Emotional responses to affective displays in others: The distinction between empathy and sympathy", Journal of Personality and Social Psychology, Vol. 51 No. 3, pp. 609-614.

Hafer, C. L., and Begue, L. (2005), "Experimental research on just-world theory: Problems, developments, and future challenges", Psychological Bulletin, Vol. 131 No. 1, pp. 128167.

Haidt, J. (2003), “The moral emotions”, in Davidson R. J., Sherer K. R., and Goldsmith H. H. (Eds.), Handbook of affective sciences, Oxford University Press: Oxford, pp. 852-870.

Hair, Jr., J. F., Black, W. C., Babin, B. J., and Anderson, R. (2010), Multivariate Data Analysis, Pearson Prentice Hall, Upper Saddle River, NJ.

Haslam, N., and Loughnan, S. (2014), "Dehumanization and infrahumanization", Annual Review of Psychology, Vol. 65, pp. 399-423.

Hayes, A. F. (2013). PROCESS: An introduction to mediation, moderation, and conditional process analysis: A regression-based approach. Guilford, New York. (http://www.afhayes.com/public/ process2012.pdf)

Higgins, E. T. (1998), "Promotion and prevention: Regulatory focus as a motivational principle", in Zanna M. P. (Ed.), Advances in experimental social psychology (Vol. 30). Academic Press, San Diego, CA, , pp. 1-46.

Joireman, J., Grégoire, Y., Devezer, B., \& Tripp, T. M. (2013). When do customers offer firms a "second chance" following a double deviation? The impact of inferred firm 
motives on customer revenge and reconciliation. Journal of Retailing, Vol. 89 No. 3, pp. $315-337$.

Kay, A. C., Jost, J. T. and Young, S. (2005), "Victim derogation and victim enhancement as alternate routes to system justification", Psychological Science, Vol. 16 No. 3, pp. 240246.

Keller, J. and Pfattheicher, S. (2013), "The compassion-hostility paradox: The interplay of vigilant, prevention-focused self-regulation, compassion, and hostility", Personality and Social Psychology Bulletin, Vol. 39 No. 11, pp. 1518-1529.

Keller, P. A., and Block, L. G. (1997). "Vividness effects: A resource-matching perspective", Journal of Consumer Research, Vol. 24 No. 3, pp. 295-304.

Kerr, G., Mortimer, K., Dickinson, S. and Waller, D. S. (2012), "Buy, boycott or blog: Exploring online consumer power to share, discuss and distribute controversial advertising messages", European Journal of Marketing, Vol. 46 No. (3/4), pp. 387-405

Kisielius, J., and Sternthal, B. (1984). "Detecting and explaining vividness effects in attitudinal judgments", Journal of Marketing Research, Vol. 21, pp. 54-64.

Kogut, T. and Ritov, I. (2005), "The "identified victim" effect: An identified group, or just a single individual?”, Journal of Behavioral Decision Making, Vol. 18 No. 3, pp. 157-167.

Kristofferson, K., White, K. and Peloza, J. (2014), "The nature of slacktivism: How the social observability of an initial act of token support affects subsequent prosocial action”, Journal of Consumer Research, Vol. 40 No. 6, pp. 1149-1166.

Lange, D. and Washburn, N. T. (2012), "Understanding attributions of corporate social irresponsibility”, Academy of Management Review, Vol. 37 No. 2, pp. 300-326.

Leidner, B., Castano, E., Zaiser, E. and Giner-Sorolla, R. (2010), "Ingroup glorification, moral disengagement, and justice in the context of collective violence", Personality and Social Psychology Bulletin, Vol. 36 No. 8, pp. 1115-1129.

Lerner, M. J. (1980). The belief in a just world: A fundamental delusion. Plenum Press, New York.

Loewenstein, G. and Small, D. A. (2007), "The Scarecrow and the Tin Man: The vicissitudes of human sympathy and caring”, Review of General Psychology, Vol. 11 No. 2, pp. 112126.

Moghe, S. (2014), "Six charged in West Virginia water contamination", $C N N$, Available at: http://edition.cnn.com/2014/12/17/justice/west-virginia-water-contamination/.

Moreno, R. (2015), “When I lost my hands making flatscreens I can't afford, nobody would help me", The Guardian, available at: 
http://www.theguardian.com/commentisfree/2015/jun/11/lost-hands-making-flatscreensno-help.

O’Mara, E. M., Jackson, L. E., Batson, C. D. and Gaertner, L. (2011), "Will moral outrage stand up?: Distinguishing among emotional reactions to a moral violation", European Journal of Social Psychology, Vol. 41 No. 2, pp. 173-179.

Pagano, S. J. and Huo, Y. J. (2007), "The role of moral emotions in predicting support for political actions in post-war Iraq", Political Psychology, Vol. 28 No. 2, pp. 227-255.

Paolacci, G. and Chandler, J. (2014), "Inside the Turk understanding Mechanical Turk as a participant pool”, Current Directions in Psychological Science, Vol. 23 No. 3, pp. 184188.

Paolacci, G., Chandler, J. and Stern, L. N. (2010), "Running experiments on Amazon Mechanical Turk", Judgement and Decision Making, Vol. 5 No. 5, pp. 411-419.

Pe'er, E., Vosgerau, J. and Acquisti, A. (2014), "Reputation as a sufficient condition for data quality on Amazon Mechanical Turk", Behavior Research Methods, Vol. 46 No. 4, pp. 1023-1031.

Podsakoff, P. M., MacKenzie, S. B., Lee, J.-Y. and Podsakoff, N. P. (2003), "Common method biases in behavioral research: a critical review of the literature and recommended remedies", Journal of Applied Psychology, Vol. 88 No. 5, pp. 879-903.

Romani, S., Grappi, S. and Bagozzi, R. P. (2013), "My Anger is your gain, my contempt your loss: explaining consumer responses to corporate wrongdoing", Psychology \& Marketing, Vol. 30 No. 12, pp. 1029-1042.

Roseman, I. J., Wiest, C. and Swartz, T. S. (1994), "Phenomenology, behaviors, and goals differentiate discrete emotions", Journal of Personality and Social Psychology, Vol. 67 No. 2, pp. 206-221.

Russell, J. A. and Fehr, B. (1994), "Fuzzy concepts in a fuzzy hierarchy: varieties of anger", Journal of Personality and Social Psychology, Vol. 67 No. 2, pp. 186-205.

Skarlicki, D. P., Ellard, J. H. and Kelln, B. R. (1998), "Third-party perceptions of a layoff: Procedural, derogation, and retributive aspects of justice", Journal of Applied Psychology, Vol. 83 No. 1, pp. 119-127.

Small, D. A. (2010), "Reference-dependent sympathy", Organizational Behavior and Human Decision Processes, Vol. 112 No. 2, pp. 151-160.

Small, D. A. and Loewenstein, G. (2003), "Helping a victim or helping the victim: Altruism and identifiability", Journal of Risk and Uncertainty, Vol. 26 No. 1, pp. 5-16.

Small, D. A. and Simonsohn, U. (2008), "Friends of victims: personal experience and prosocial behavior", Journal of Consumer Research, Vol. 35 No. 3, pp. 532-542. 
Steenkamp, J. B. E. and Baumgartner, H. (1998), “Assessing measurement invariance in cross-national consumer research", Journal of Consumer Research, Vol. 25 No. 1, pp. 78107.

Stürmer, S., Snyder, M. and Omoto, A. M. (2005), "Prosocial emotions and helping: the moderating role of group membership", Journal of Personality and Social Psychology, Vol. 88 No. 3, pp. 532-546.

Trivers, R. L. (1971), “The evolution of reciprocal altruism”, Quarterly Review of Biology, Vol. 46, pp. 35-57.

Van Kleef, G. A., De Dreu, C. K. and Manstead, A. S. (2010), “An interpersonal approach to emotion in social decision making: The emotions as social information model", Advances in Experimental Social Psychology, Vol. 42, pp. 45-96.

Vreeke, G. J. and Van der Mark, I. L. (2003), "Empathy, an integrative model”, New Ideas in Psychology, Vol. 21 No. 3, pp. 177-207.

Weiner, B. (1985), "An attributional theory of achievement motivation and emotion", Psychological Review, Vol. 92 No. 4, pp. 548-573.

Weiner, B. (1993), “On Sin versus Sickness”, American Psychologist, Vol. 48 No. 9, 957965.

Wispe, L. (1986), "The distinction between sympathy and empathy: To call forth a concept, a word is needed", Journal of Personality and Social Psychology, Vol. 50 No. 2, pp. 314321 .

Xie, C., Bagozzi, R. P. and Grønhaug, K. (2015), "The role of moral emotions and individual differences in consumer responses to corporate green and non-green actions", Journal of the Academy of Marketing Science, Vol. 43 No. 3, pp. 333-356.

Zahavi, D. (2008), "Simulation, projection and empathy", Consciousness and Cognition, Vol. 17 No. 2, pp. 514-522.

Zaki, J. (2014), “Empathy: A motivated account”, Psychological Bulletin, Vol. 140 No. 6, pp. 1608-1647.

Zhao, X., Lynch Jr., J. G., \& Chen, Q. (2010). Reconsidering Baron and Kenny: Myths and Truths about Mediation Analysis. Journal of Consumer Research, 37(2), 197-206. doi:10.1086/651257 


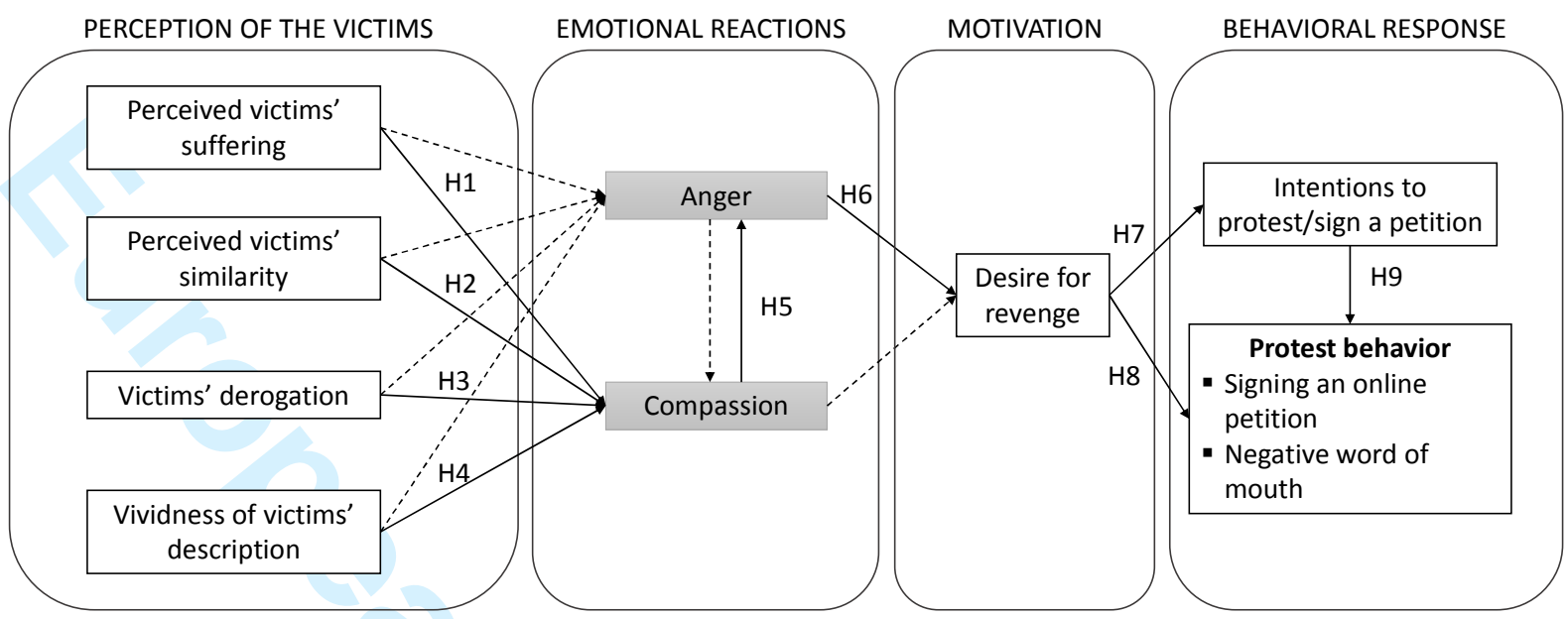

Solid lines indicate hypothesized paths; dashed lines indicate paths analyzed to rule out alternative explanations.

\section{Figure 1: Conceptual model}


Additional paths controlled for in the model:

Blame $\rightarrow$ Compassion $\quad 22^{*}$ Unfairness $\rightarrow$ Compassion $\quad .04^{\mathrm{NS}}$ Blame $\rightarrow$ Anger

Unfairness $\rightarrow$ Anger $\quad .14^{\text {NS }}$

$\beta$ represents standardized path coefficients. ${ }^{*} p<.05 ;{ }^{* *} p<.01$.

\section{Figure 2: Structural model (Study 1)}




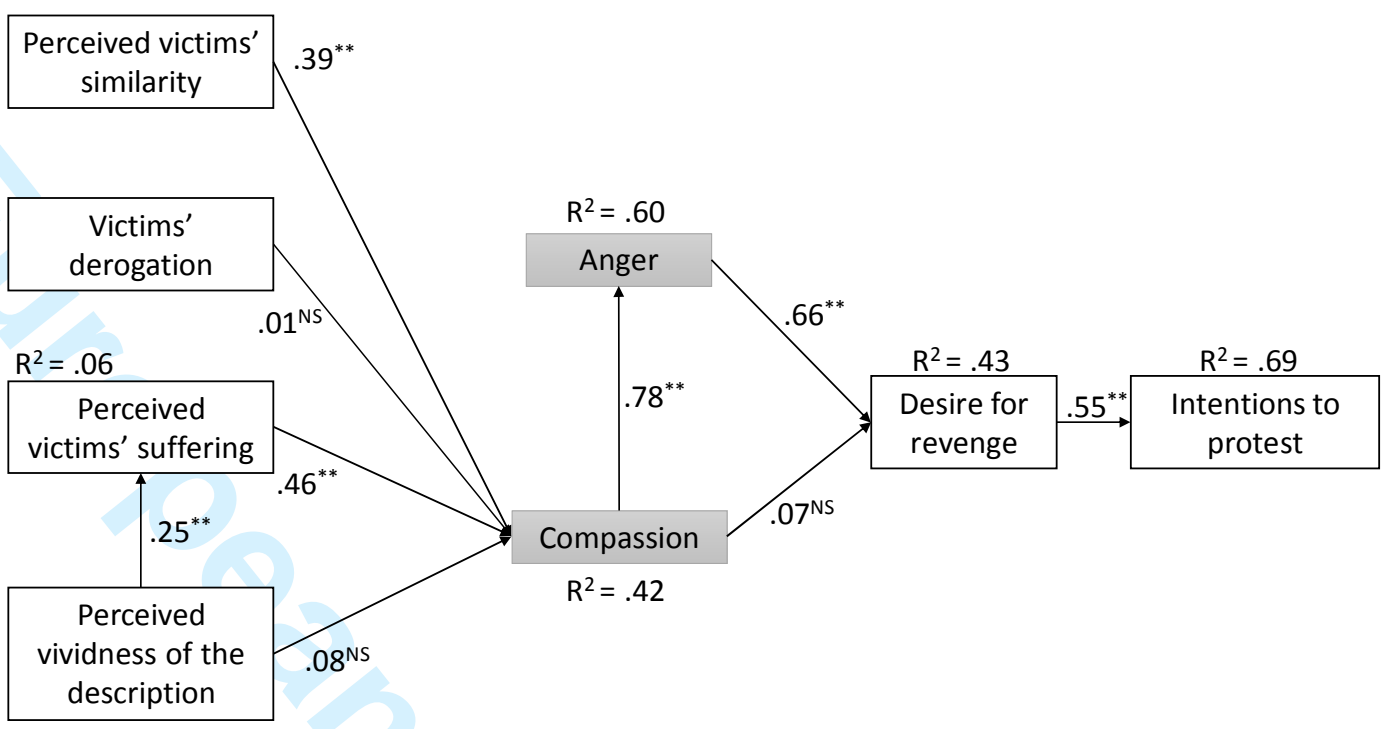

$\beta$ represents standardized path coefficients. ${ }^{*} p<.05 ;{ }^{* *} p<.01$.

Figure 3: Structural model (Study 2) 
Table 1: Comparison of alternative models (Study 1)

\begin{tabular}{|l|c|c|c|c|c|c|c|c|c|}
\hline & $\chi^{2}$ & $d f$ & $C F I$ & $T L I$ & $R M S E A$ & $S R M R$ & $A I C$ & $P C F I$ & $P G F I$ \\
\hline Model A & 650.47 & 450 & 0.947 & 0.942 & 0.054 & 0.092 & 806.466 & 0.860 & 0.685 \\
\hline Model B & 644.05 & 444 & 0.948 & 0.941 & 0.054 & 0.090 & 812.052 & 0.848 & 0.677 \\
\hline Model C & 703.34 & 450 & 0.934 & 0.927 & 0.060 & 0.151 & 859.338 & 0.847 & 0.676 \\
\hline Model D & 696.84 & 444 & 0.934 & 0.926 & 0.061 & 0.149 & 864.835 & 0.836 & 0.668 \\
\hline Model E & 649.46 & 447 & 0.947 & 0.941 & 0.054 & 0.092 & 811.459 & 0.853 & 0.681 \\
\hline Model F & 643.04 & 441 & 0.947 & 0.940 & 0.054 & 0.090 & 817.039 & 0.842 & 0.672 \\
\hline
\end{tabular}

Model A: Full mediation through Compassion

Model B: Partial mediation through Compassion

Model C: Full mediation through Anger

Model D: Partial mediation through Anger

Model E: Full mediation through both Compassion and Anger

Model F: Partial mediation through both Compassion and Anger 
Table 2: Indirect effects (Study 1)

\begin{tabular}{|c|c|c|c|}
\hline & Indirect effect tested & Estimate & $\begin{array}{c}\text { Confidence } \\
\text { interval }\end{array}$ \\
\hline $\begin{array}{l}\text { Conceptual } \\
\text { path }\end{array}$ & $\begin{array}{l}\text { Victims' similarity } \rightarrow \text { Compassion } \rightarrow \text { Anger } \rightarrow \text { Revenge } \rightarrow \\
\text { Intentions to sign the petition } \rightarrow \text { Signed the petition }\end{array}$ & .02 & $\begin{array}{l}\text { from } .006 \\
\text { to } .05\end{array}$ \\
\hline $\begin{array}{l}\text { Alternative } \\
\text { path }\end{array}$ & $\begin{array}{l}\text { Victims' similarity } \rightarrow \text { Anger } \rightarrow \text { Compassion } \rightarrow \text { Revenge } \rightarrow \\
\text { Intentions to sign the petition } \rightarrow \text { Signed the petition }\end{array}$ & .001 & $\begin{array}{l}\text { from }-.008 \\
\quad \text { to } .01\end{array}$ \\
\hline $\begin{array}{l}\text { Conceptual } \\
\text { path }\end{array}$ & $\begin{array}{l}\text { Victims' similarity } \rightarrow \text { Compassion } \rightarrow \text { Anger } \rightarrow \text { Revenge } \rightarrow \\
\text { Intentions to sign the petition } \rightarrow \text { Negative word of mouth }\end{array}$ & .01 & $\begin{array}{l}\text { from } .002 \\
\text { to } .02\end{array}$ \\
\hline $\begin{array}{l}\text { Alternative } \\
\text { path }\end{array}$ & $\begin{array}{l}\text { Victims' similarity } \rightarrow \text { Anger } \rightarrow \text { Compassion } \rightarrow \text { Revenge } \rightarrow \\
\text { Intentions to sign the petition } \rightarrow \text { Negative word of mouth }\end{array}$ & 0.001 & $\begin{array}{l}\text { from }-.003 \\
\text { to } .005\end{array}$ \\
\hline $\begin{array}{l}\text { Conceptual } \\
\text { path }\end{array}$ & $\begin{array}{l}\text { Victims' derogation } \rightarrow \text { Compassion } \rightarrow \text { Anger } \rightarrow \text { Revenge } \rightarrow \\
\text { Intentions to sign the petition } \rightarrow \text { Signed the petition }\end{array}$ & -.02 & $\begin{array}{c}\text { from }-.06 \text { to } \\
-.007\end{array}$ \\
\hline $\begin{array}{l}\text { Alternative } \\
\text { path }\end{array}$ & $\begin{array}{l}\text { Victims' derogation } \rightarrow \text { Anger } \rightarrow \text { Compassion } \rightarrow \text { Revenge } \rightarrow \\
\text { Intentions to sign the petition } \rightarrow \text { Signed the petition }\end{array}$ & .0008 & $\begin{array}{l}\text { from } .006 \\
\text { to } .01\end{array}$ \\
\hline $\begin{array}{l}\text { Conceptual } \\
\text { path }\end{array}$ & $\begin{array}{l}\text { Victims' derogation } \rightarrow \text { Compassion } \rightarrow \text { Anger } \rightarrow \text { Revenge } \rightarrow \\
\text { Intentions to sign the petition } \rightarrow \text { Negative word of mouth }\end{array}$ & -.01 & $\begin{array}{c}\text { from }-.03 \text { to } \\
-.003\end{array}$ \\
\hline $\begin{array}{l}\text { Alternative } \\
\text { path }\end{array}$ & $\begin{array}{l}\text { Victims' derogation } \rightarrow \text { Anger } \rightarrow \text { Compassion } \rightarrow \text { Revenge } \rightarrow \\
\text { Intentions to sign the petition } \rightarrow \text { Negative word of mouth }\end{array}$ & .0004 & $\begin{array}{l}\text { from }-.002 \\
\text { to } .005\end{array}$ \\
\hline $\begin{array}{l}\text { Conceptual } \\
\text { path }\end{array}$ & $\begin{array}{l}\text { Victims' suffering } \rightarrow \text { Compassion } \rightarrow \text { Anger } \rightarrow \text { Revenge } \rightarrow \\
\text { Intentions to sign the petition } \rightarrow \text { Signed the petition }\end{array}$ & .03 & $\begin{array}{c}\text { from } .01 \\
\text { to } .08\end{array}$ \\
\hline $\begin{array}{l}\text { Alternative } \\
\text { path }\end{array}$ & $\begin{array}{l}\text { Victims' suffering } \rightarrow \text { Anger } \rightarrow \text { Compassion } \rightarrow \text { Revenge } \rightarrow \\
\text { Intentions to sign the petition } \rightarrow \text { Signed the petition }\end{array}$ & -.001 & $\begin{array}{l}\text { from }-.01 \\
\text { to. } 007\end{array}$ \\
\hline $\begin{array}{l}\text { Conceptual } \\
\text { path }\end{array}$ & $\begin{array}{l}\text { Victims' suffering } \rightarrow \text { Compassion } \rightarrow \text { Anger } \rightarrow \text { Revenge } \rightarrow \\
\text { Intentions to sign the petition } \rightarrow \text { Negative word of mouth }\end{array}$ & .01 & $\begin{array}{l}\text { from } .003 \\
\text { to } .03\end{array}$ \\
\hline $\begin{array}{l}\text { Alternative } \\
\text { path }\end{array}$ & $\begin{array}{l}\text { Victims' suffering } \rightarrow \text { Anger } \rightarrow \text { Compassion } \rightarrow \text { Revenge } \rightarrow \\
\text { Intentions to sign the petition } \rightarrow \text { Negative word of mouth }\end{array}$ & -.001 & $\begin{array}{l}\text { from }-.006 \\
\text { to } .002\end{array}$ \\
\hline
\end{tabular}

$\beta$ represents unstandardized path coefficients. Each effect is calculated using PROCESS, Model 6 (Hayes, 2013 ) 


\section{Table 3: Indirect effects (Study 1, replication)}

\begin{tabular}{|l|l|c|l|}
\hline & \multicolumn{1}{|c|}{ Indirect effect tested } & Estimate & Confidence interval \\
\hline $\begin{array}{l}\text { Conceptual } \\
\text { path }\end{array}$ & $\begin{array}{l}\text { Victim's similarity } \rightarrow \text { Compassion } \rightarrow \text { Anger } \rightarrow \\
\text { Revenge } \rightarrow \text { Intentions to sign the petition }\end{array}$ & 0.05 & from .03 to .09 \\
\hline $\begin{array}{l}\text { Alternative } \\
\text { path }\end{array}$ & $\begin{array}{l}\text { Victim's similarity } \rightarrow \text { Anger } \rightarrow \text { Compassion } \rightarrow \\
\text { Revenge } \rightarrow \text { Intentions to sign the petition }\end{array}$ & 0.009 & from -.01 to .03 \\
\hline $\begin{array}{l}\text { Conceptual } \\
\text { path }\end{array}$ & $\begin{array}{l}\text { Victim's derogation } \rightarrow \text { Compassion } \rightarrow \text { Anger } \rightarrow \\
\text { Revenge } \rightarrow \text { Intentions to sign the petition }\end{array}$ & -0.08 & from -.11 to -.05 \\
\hline $\begin{array}{l}\text { Alternative } \\
\text { path }\end{array}$ & $\begin{array}{l}\text { Victim's derogation } \rightarrow \text { Anger } \rightarrow \text { Compassion } \rightarrow \\
\text { Revenge } \rightarrow \text { Intentions to sign the petition }\end{array}$ & -0.001 & from -.02 to .01 \\
\hline $\begin{array}{l}\text { Conceptual } \\
\text { path }\end{array}$ & $\begin{array}{l}\text { Victim's suffering } \rightarrow \text { Compassion } \rightarrow \text { Anger } \rightarrow \\
\text { Revenge } \rightarrow \text { Intentions to sign the petition }\end{array}$ & 0.08 & from .05 to .12 \\
\hline $\begin{array}{l}\text { Alternative } \\
\text { path }\end{array}$ & $\begin{array}{l}\text { Victim's suffering } \rightarrow \text { Anger } \rightarrow \text { Compassion } \rightarrow \\
\text { Revenge } \rightarrow \text { Intentions to sign the petition }\end{array}$ & 0.01 & from -.01 to .04 \\
\hline
\end{tabular}

$\beta$ represents unstandardized path coefficients. Each effect is calculated using PROCESS, Model 6 (Hayes, 2013 ). 
Table 4: Descriptive statistics and correlations (Study 2)

\begin{tabular}{|c|c|c|c|c|c|c|c|c|c|c|c|}
\hline & $\begin{array}{l}\text { Violation } \\
\text { and } \\
\text { vividness }\end{array}$ & $\begin{array}{l}\text { Violation } \\
\text { only }\end{array}$ & & & & & & & & \\
\hline & & $\mathrm{N}=98$ & $\mathrm{~N}=96$ & 1. & 2. & 3. & 4. & 5. & 6. & 7. & 8. \\
\hline \multirow{2}{*}{$\begin{array}{l}\text { 1. Perceived } \\
\text { vividness of the } \\
\text { description }\end{array}$} & Mean & $5.41^{* *}$ & 4.64 & \multirow{2}{*}{ - } & & & & & & & \\
\hline & $S D$ & .94 & 1.37 & & & & & & & & \\
\hline \multirow{2}{*}{$\begin{array}{l}\text { 2. Perceived } \\
\text { victims' similarity }\end{array}$} & Mean & 4.40 & 4.20 & \multirow{2}{*}{.13} & \multirow{2}{*}{-} & & & & & & \\
\hline & $S D$ & 1.11 & 1.14 & & & & & & & & \\
\hline \multirow{2}{*}{$\begin{array}{l}\text { 3. Victims' } \\
\text { derogation }\end{array}$} & Mean & 3.22 & 3.50 & \multirow{2}{*}{-.06} & \multirow{2}{*}{$-.33^{* *}$} & \multirow{2}{*}{-} & & & & & \\
\hline & $S D$ & 1.81 & 1.60 & & & & & & & & \\
\hline \multirow{2}{*}{$\begin{array}{l}\text { 4. Perceived } \\
\text { victims'suffering }\end{array}$} & Mean & $5.49^{*}$ & 5.09 & \multirow{2}{*}{$.19^{* *}$} & \multirow{2}{*}{$.25^{* *}$} & \multirow{2}{*}{$-.23^{* *}$} & \multirow{2}{*}{-} & & & & \\
\hline & $S D$ & 1.26 & 1.28 & & & & & & & & \\
\hline \multirow{2}{*}{ 5. Compassion } & Mean & $4.87^{* *}$ & 4.20 & \multirow{2}{*}{$.19^{* *}$} & \multirow{2}{*}{$.41^{* *}$} & \multirow{2}{*}{$-.25^{* *}$} & \multirow{2}{*}{$.45^{* *}$} & \multirow{2}{*}{-} & & & \\
\hline & $S D$ & 1.34 & 1.50 & & & & & & & & \\
\hline \multirow{2}{*}{ 6. Anger } & Mean & 4.52 & 4.14 & \multirow{2}{*}{$.22^{* *}$} & \multirow{2}{*}{$.36^{* *}$} & \multirow{2}{*}{-.13} & \multirow{2}{*}{$.45^{* *}$} & \multirow{2}{*}{$.63^{* *}$} & \multirow{2}{*}{ - } & & \\
\hline & $S D$ & 1.69 & 1.67 & & & & & & & & \\
\hline \multirow{2}{*}{$\begin{array}{l}\text { 7. Desire for } \\
\text { revenge }\end{array}$} & Mean & 4.83 & 4.76 & \multirow{2}{*}{.13} & \multirow{2}{*}{$.36^{* *}$} & \multirow{2}{*}{$-.16^{*}$} & \multirow{2}{*}{$.29^{* *}$} & \multirow{2}{*}{$.40^{* *}$} & $64^{* *}$ & & \\
\hline & $S D$ & 1.45 & 1.41 & & & & & & .04 & - & \\
\hline & Mean & 4.53 & 4.33 & & & & & & & & \\
\hline 8. Intentions to & $S D$ & 1.45 & 1.46 & $.21^{* *}$ & $.37^{* *}$ & -.12 & $.33^{* *}$ & $.48^{* *}$ & $.65^{* *}$ & $.69^{* *}$ & - \\
\hline & $S D$ & .94 & 1.37 & & & & & & & & \\
\hline
\end{tabular}

${ }^{*} p<.05 ;{ }^{* *} p<.01$ 
Table 5: Mediation model (Study 2)

\begin{tabular}{|c|c|c|}
\hline Hypothesized paths & $\beta ;$ SE; t-statistic & Bias-corrected CI \\
\hline $\begin{array}{l}\text { Vividness manipulation } \rightarrow \text { Perceived victims' } \\
\text { suffering }\end{array}$ & $.20^{*} ; .09 ; 2.02$ & from .02 to .38 \\
\hline Perceived victims' suffering $\rightarrow$ Compassion & $.48^{*} ; .09 ; 6.62$ & from .34 to .63 \\
\hline Compassion $\rightarrow$ Anger & $.62^{* *} ; .07 ; 8.61$ & from .48 to .76 \\
\hline Anger $\rightarrow$ Desire for Revenge & $.54^{* * *} ; .06 ; 8.66$ & from .42 to .66 \\
\hline Desire for Revenge $\rightarrow$ Intentions to protest & $.47^{* *} ; .06 ; 7.21$ & from .34 to .59 \\
\hline Hypothesized indirect effects & $\beta$ & Bias-corrected CI \\
\hline $\begin{array}{l}\text { Vividness manipulation } \rightarrow \text { Perceived victims' } \\
\text { suffering } \rightarrow \text { Compassion }\end{array}$ & .09 & from .02 to .19 \\
\hline $\begin{array}{l}\text { Vividness manipulation } \rightarrow \text { Perceived victims' } \\
\text { suffering } \rightarrow \text { Compassion } \rightarrow \text { Anger }\end{array}$ & .06 & from .01 to .13 \\
\hline $\begin{array}{l}\text { Vividness manipulation } \rightarrow \text { Perceived victims' } \\
\text { suffering } \rightarrow \text { Compassion } \rightarrow \text { Anger } \rightarrow \text { Desire for } \\
\text { Revenge }\end{array}$ & .03 & from .006 to .07 \\
\hline $\begin{array}{l}\text { Vividness manipulation } \rightarrow \text { Perceived victims' } \\
\text { suffering } \rightarrow \text { Compassion } \rightarrow \text { Anger } \rightarrow \text { Desire for } \\
\text { Revenge } \rightarrow \text { Intentions to protest }\end{array}$ & .02 & from .003 to .04 \\
\hline \multicolumn{3}{|l|}{$\begin{array}{l}\text { Hypothesized indirect effects (with victims' } \\
\text { similarity and victims' derogation as covariates) }\end{array}$} \\
\hline $\begin{array}{l}\text { Vividness manipulation } \rightarrow \text { Perceived victims' } \\
\text { suffering } \rightarrow \text { Compassion }\end{array}$ & .06 & from .002 to .15 \\
\hline $\begin{array}{l}\text { Vividness manipulation } \rightarrow \text { Perceived victims' } \\
\text { suffering } \rightarrow \text { Compassion } \rightarrow \text { Anger }\end{array}$ & .04 & from .002 to .09 \\
\hline $\begin{array}{l}\text { Vividness manipulation } \rightarrow \text { Perceived victims' } \\
\text { suffering } \rightarrow \text { Compassion } \rightarrow \text { Anger } \rightarrow \text { Desire for } \\
\text { Revenge }\end{array}$ & .02 & from .001 to .05 \\
\hline $\begin{array}{l}\text { Vividness manipulation } \rightarrow \text { Perceived victims' } \\
\text { suffering } \rightarrow \text { Compassion } \rightarrow \text { Anger } \rightarrow \text { Desire for } \\
\text { Revenge } \rightarrow \text { Intentions to protest }\end{array}$ & .008 & from .001 to .03 \\
\hline
\end{tabular}

$\beta$ represents unstandardized path coefficients. ${ }^{* *} p<.001$. Indirect effects are calculated through the estimation of four regression models. We used Model 4 to calculate indirect effects of the manipulation on the dependent variables through one mediator and Model 6 to calculate indirect effects of the manipulations on the dependent variables through two mediators. Victims' similarity and derogation are retained as covariates in the analysis. 